\title{
MONETARY POLICY IN JAPAN, GERMANY AND THE UNITED STATES: \\ DOES ONE SIZE FIT ALL?
}

Menzie D. Chinn

Michael P. Dooley

Working Paper 6092
NATIONAL BUREAU OF ECONOMIC RESEARCH 1050 Massachusetts Avenue
Cambridge, MA 02138
July 1997

\begin{abstract}
We thank Ramon Moreno for comments and Hui Miao for research assistance. This research was supported by faculty research funds of UCSC. This paper is part of NBER's research program in International Finance and Macroeconomics. Any opinions expressed are those of the authors and not those of the National Bureau of Economic Research.

(C) 1997 by Menzie D. Chinn and Michael P. Dooley. All rights reserved. Short sections of text, not to exceed two paragraphs, may be quoted without explicit permission provided that full credit, including $\mathbb{C}$ notice, is given to the source.
\end{abstract}


Monetary Policy in Japan, Germany and the United

States: Does One Size Fit All?

Menzie D. Chinn and Michael P. Dooley

NBER Working Paper No. 6092

July 1997

JEL Nos. E52, E43

International Finance and Macroeconomics

\section{ABSTRACT}

We study the post-war evidence for Japan to see if the same specification for both the economy and the monetary policy rule is useful for understanding Japan's economy and monetary policy. A recurrent theme in the literature on Japanese monetary policy is that there are significant differences in both the policy procedures and objectives as compared to other industrial countries. In this paper we propose an "out of sample" test of a set of restrictions on a vector autoregression employed by Clarida and Gertler (1997) in their analysis of the Bundesbank's behavior. Our interpretation of the evidence is that, with minor adjustments, the same specification provides a useful framework for understanding monetary policy in Japan. Perhaps the most interesting finding is that the Bank of Japan appears to react to inflation over longer forecast horizons as compared to other central banks.

Menzie D. Chinn

Department of Economics

Social Sciences I

University of California

Santa Cruz, CA 95064

and NBER

chinn@cats.ucsc.edu
Michael P. Dooley

Department of Economics

Social Sciences I

University of California

Santa Cruz, CA 95064

and NBER

mpd@cats.ucsc.edu 


\section{Introduction}

Recent empirical studies of monetary policies in the United States and Germany suggest that a simple reaction function provides a useful description of Federal Reserve and Bundesbank policy. This reaction function posits that the monetary authorities manage an overnight interest rate in order to limit predicted deviations in inflation and employment from target levels.

In this paper we study post-war evidence for Japan to see if the same specification for both the economy and the monetary policy rule is useful for understanding Japan's economy and monetary policy. A recurrent theme in the literature on monetary policy in Japan is that there are significant differences in the both policy procedures and objectives as compared to other industrial countries.

For example, there is considerable support for the view that the Bank of Japan regards the exchange rate as a policy goal (Hutchison, 1988; Glick and Hutchison, 1994). Moreover the structure of financial markets and the nature of the transmission mechanism also appear to be quite dissimilar in Japan as compared to other industrial countries. The relatively late and gradual decontrol of interest rates in Japan is frequently cited as a factor that has made quantitative control of credit aggregates an important policy tool. Research reported in Chinn and Dooley (1996) suggests that the transmission mechanism in Japan seems atypical of industrial countries. In particular, time series evidence for Japan suggests that a credit view of the transmission mechanism might be relevant for Japan.

Finally, economists have drawn quite different conclusions about the relative importance of monetary aggregates and interest rates as the Bank of Japan's policy tool. Friedman (1984) observed that "Japan illustrates a policy that is less monetarist in rhetoric than the policies followed in the United States and Great Britain but far more monetarist in practice." In contrast, Ito (1989) examined the behavior of the Bank of Japan over the same period and concluded that "the Bank of Japan did not practice what monetarism 
preached... In particular, when there is an unexpected jump in money supply, the base is adjusted to a new level (bygones are bygones) and a further accommodation in growth is allowed in new "forecast." Ito (1989: 24) also observes "An oral tradition among experts on monetary policy suggests ... [t] he Bank of Japan was politically defeated in 1972 and was forced to lower the discount rate against its will... Therefore having money supply established as a "target" the Bank now has a contingent weapon in order to implement a necessary tightening (or interest rate hike) when it is needed." If a simple "international" reaction function captures monetary policy in Japan it would be an important step toward resolving these issues.

Any set of restrictions that produce "sensible" parameter estimates for comovements of important economic variables and for policy reaction functions for a single country are suspect in that the researcher has wide discretion in adjusting the restrictions in order to justify preconceived ideas about how the economy and the central bank interact. In this paper we propose an "out of sample" test of a set of restrictions on a vector autoregression proposed by Clarida and Gertler (1997). If these restrictions really are economically meaningful they might also produce sensible results for Japan. If they are not meaningful, the chance that they would produce sensible results for Japan is remote. Our interpretation of the evidence presented below is that, with minor adjustments, the same specification provides a useful framework for understanding monetary policy in Japan. Perhaps the most interesting finding is that the Bank of Japan appears to react to inflation over longer forecast horizons as compared to other central banks.

\section{Identifying the Bank of Japan's Policy Reaction Function}

Clarida and Gertler (1997) provide an interesting identification strategy for monetary policy. First they argue that in a simple vector autoregression representation all past values of variables are determinants of current policies. In contrast contemporaneous variables are naturally separated into those that are jointly determined with the policy tool -- short 
term interest rates, such as exchange rates and long term interest rates -and those which are contemporaneously independent of the policy tool such as economic activity and prices. The set of jointly determined variables are, of course, not independent. In principle, the central bank could choose any such variable as the "policy tool" and simply solve for values for all the other contemporaneously determined variables. In practice, central banks apparently believe that a short term interest rate is the preferred variable to control. Figure 1 depicts several short term interest rates, including the money market rate used in our analysis.

The basic identification problem is that central banks are to some extent driven by economic variables and at the same time changes in the policy instruments influence a subset of contemporaneously determined variables. Although the dynamics of this process are difficult to disentangle, there is a general consensus on how to approach the problem. The standard methodology for doing so entails use of some semi-structural modeling approach, such as a structural VAR. Recent examples of this literature include Blanchard (1989), Gali (1992), Walsh (1993), Bernanke and Mihov (1995). A recent application to the Japanese case is Kasa and Popper (1996).

The Clarida and Gertler approach to the problem is to place some restrictions on the influence that innovations (forecast errors) for some variables have on innovations of others. The first set of exclusion restrictions divide variables into those that are predetermined in the time period (a month) and those that are determined along with the policy variable. Predetermined variables include retail sales, the consumer price index, world commodity prices and the US interest rate. Contemporaneous policy variables include the short term interest rate, the exchange rate and the money supply.

A virtue of this approach to identifying an economic system is that the nature of the restrictions is fairly transparent. Nevertheless, it is clear that a good deal of art has gone into this set of restrictions. We can get a feel for the plausibility of the restrictions by examining the impulse reaction functions to innovations in each of the variables. The specification 
"test" is simply a comparison of what we think is reasonable with what the data suggest, subject to the restrictions described above. While some set of restrictions will probably force the data to confess to any preconception idea about how an individual econormy works, it is unlikely that a specification that merely fits a data set will travel well to other countries.

\subsection{A General Structural VAR}

Following Clarida and Gertler let $y_{t}$ be $m \times 1$ vector macroeconomic variables and $e_{t}$ be an associated vector structural disturbances. The elements of $e_{t}$ are assumed to be mutually orthogonal i.i.d. disturbances. They are interpreted as being the exogenous shocks that drive the economy.

A general, nonstructural, expression that characterizes the time series evolution of the vector $y_{t}$ is given by:

$$
y_{t}=C y_{t}+\sum_{i=1}^{\infty} A_{i} y_{t-i}
$$

where $C$ and $A_{1}$ are $m \times m$ matrices of coefficients, and where the diagonal elements of $C$ are equal to zero. Equation (1) expresses each element of $y_{t}$ as a function of lags of itself, and the current as well as lagged values of all the other variables in the system.

The key issue is to restrict certain elements of the $\mathrm{C}$ matrix to be zero; this in effect sets certain contemporaneous effects to zero. Once one estimates the C matrix, one can calculate the underlying "exogenous" shocks to the economy (the $e_{t}^{\prime} s$ ); then using these $e_{t}{ }^{\prime} s$ and a transformation of the $C$ matrix, one can trace out the impact of each of these shocks on the economy. In particular, one obtains a reaction function for each policy element of $y_{t}$.

In practice, the coefficients are estimated by working with the forecast errors from a reduced form VAR incorporating the restrictions, $u_{t}$. To see this, consider re-writing (1): 


$$
y_{t}=\sum_{i=1}^{\infty} B_{i} y_{t-i}+u_{t}
$$

where

$$
B_{i}=(I-C)^{-1} A_{i} \text { and } u_{t}=(I-C)^{-1} e_{t}
$$

Then the optimal forecast of $y_{t}$ (based on the variables in the VAR) is given by (2). The forecast error is

$$
u_{t} \equiv y_{t}-E_{t-1} y_{t}
$$

Then estimating:

$$
u_{t}=C u_{t}+e_{t}
$$

\subsection{Defining the Policy and Information Variables}

We take as the policy variables the same ones as Clarida and Gertler (1997): the direct policy instrument (the overnight interest rate), as well as any other variable that is indirectly influenced by the central bank within the period. This includes the money stock and the exchange rate.

The non-policy variables are those that, by assumption, do not respond within the period to the policy variables. These domestic non-policy variables are industrial production, retail sales, and prices. Foreign influences are represented by commodity prices and the US Federal Funds rate. We diverge from the Clarida-Gertler model by including a variable representing bank credit. This addition is justified by the apparent behavior of the Bank of Japan, as discussed above.

The causal ordering adopted for the non-policy variable block is uncontroversial: commodity prices ( $(p)$ ), industrial production (ip), retail sales (ret), bank credit (bc), prices (CPI), and the US Fed Funds rate (ff). The placement of the first two variables is clearly standard. The location of the subsequent variables is debatable, but the results are not sensitive to 
the particular ordering of these variables.

Within the policy variable block of the short term interest rate (rs), real money stock ( $m$ ) and the real exchange rate (er), the identification scheme is as follows. Money demand and supply are given as:

$$
\begin{gathered}
u^{m}=\alpha_{1}^{r e t}+\alpha_{2} u^{r s}+e^{m} \\
u^{r s}=\beta_{1} u^{c p}+\beta_{2} u^{m}+\beta_{3} u^{e r}+e^{r s}
\end{gathered}
$$

respectively (suppressing the time subscripts).

The exchange rate is assumed to respond to all the stnuctural and nonstructural shocks, so there are no restrictions placed on this variable's behavior.

This identification scheme differs slightly from Clarida-Gertler, in that money demand [equation (6)] depends upon retail sales, instead of industrial production. The main reason for this specification is empirical: inclusion of industrial production as a proxy for income yields an incorrectly signed income elasticity. Hence, we use retail sales, which presumably proxies more accurately for transactions demand for money (it also has the correct sign when included in the regression).

Equation (7) is the key equation, as it represents how the Bank of Japan reacts to various exogenous shocks and through which channels. The Bank of Japan is assumed to react directly only to commodity price, exchange rate forecast surprises and innovations in money demand. It reacts indirectly to the US Federal Funds rate and other non-policy variables through the exchange rate.

\subsection{Data, Sample Period and Specification}

The data frequency is monthly. When relying upon identification schemes that impose zero restrictions on some contemporaneous effects, it is crucial to use the highest frequency data available, and consequently monthly data is the best choice. All the important non-policy variables are available (while, 
for instance, industrial production is not available at higher frequency). The data are drawn from the International Monetary Fund's International Financial Statistics database (July 1996 CD-ROM) and extend from 1974:08 to 1994:12. Details are provided in the Data Appendix.

The interest rate is the overnight repurchase rate. The money supply is broad money (narrow money plus quasi money) deflated by the Japanese CPI. The exchange rate is the Yen/Dollar rate adjusted by the Japanese and US CPI. The commodity price variable is the world commodity price index (based on US\$ prices), converted into Yen equivalent using the exchange rate, and deflated by the Japanese CPI. The industrial production and retail sales are real indices. The bank credit variable is total credit extended to the private sector. The price variable is the Japanese CPI. Several of the key variables are depicted in Figures 2 and 3.

We estimate the nine variable VAR entering all the variables (except interest rates) as first differences of the logged variables. Two cointegrating vectors are also included as error correction terms:

$$
\begin{aligned}
& (m-i p) \\
& (\text { ret }-i p)
\end{aligned}
$$

so that, technically, the specification is a vector error correction model (VECM) .

These long run restrictions are theoretically plausible. They impose stationary long run velocity (after allowing for a deterministic trend) and a long run relationship between sales and income. They are also empirically justifiable, since cointegration tests reject the no cointegration null hypothesis.

The VAR is ordered as:

$$
(\Delta c p, \Delta i p, \Delta r e t, \Delta b c, \Delta p, f f r, r s, \Delta m, \Delta e r \mid(m-i p),(\text { ret-ip)) }
$$

where the | separates the error correction terms, which are treated as exogenous.

We include lags of up to 12 months to account for the seasonality in 
Japanese data. However, for the sake of parsimony, we include only lags 1-3, 6 , and 12 .

\subsection{Enpirical Results}

In Table 1, the results of the key regressions are reported. Consider the first regression. This equation states that innovations in money demand respond positively to innovations in retail sales, a proxy for transactions demand, and negatively to interest rate shocks. This accords remarkably well with theory, although none of the coefficients are statistically significant.

Next consider the exchange rate equation. Most of the coefficients are not statistically significant. However, those that are significant conform to theory; a positive innovation in the Japanese short term interest rate appreciates the Yen, while one to the US Federal Funds rate depreciates it.

The Bank of Japan's behavior is summarized in the second equation. It states that the Bank of Japan responds to a positive cormodity price shock by allowing the short term interest rate to rise. A one percent innovation in commodity prices induces a 3 basis point increase in interest rates. On the other hand, there is no apparent response to money demand shocks. This implies that shocks to money demand are fully accommodated in order to smooth interest rates. An exchange rate shock also has some effect, according to the point estimate. The monetary authority increases interest rates in response to an exchange rate innovation. The estimate is not, however, statistically significant. The weakness of these results may reflect the fact that the Bank of Japan does not react strongly within the month to innovations in the other variables and rather focuses more on lagged information. This is Clarida and Gertler's interpretation of similar results for the Bundesbank.

One would like to know if the estimates implicit in these regressions are consistent with our views of the propagation mechanism. In Figure 5a, impulse response functions are shown for a variety of shocks. The variance decomposition for the interest rate is presented in Table 2 .

The graphs indicate that, for instance, the response of the interest 
rate to an industrial production shock makes sense--it rises over time.

Interest rates also rise in response to an inflation shock. A US Federal Funds shock also raises Japanese short term interest rates, while depreciating the Yen.

Notice that the responses of key variables to a shock in the short term interest rate make sense: industrial production drops and the exchange rate appreciates. The finding that inflation rises immediately after the interest rate shock is counterintuitive, but is a common finding, for both the US and Germany. An historical decomposition of the short term rate is presented in Figure 6.

\section{A More Structural Interpretation of Bank of Japan Policy: Output and Inflation Targets}

The reaction function derived in Section 3 above is rich in its implications. It provides, for instance, the reaction of the unforecastable component of the policy instrument to a shock in commodity prices. However, it is difficult to compare the estimated reaction function to objectives that a typical observer would think important -- such as inflation and output, and perhaps other variables. Hence, in this section, we express the short term interest rate as a function of expected deviations from target output and target inflation.

While this approach is seemingly quite different from that reported in the previous section, in fact the two are consistent in the sense that the "expected" values of inflation and output, as well as the estimated target output and inflation rates, are derived from the VECM of the previous section. This means that the modeling of expectations and long-run equilibria is not purely ad hoc.

\subsection{The Reaction Function}

Let $\mathbf{r s}_{\mathrm{t}}$ be the nominal interest rate, $\mathbf{r s}_{\mathrm{t}}{ }^{0}$ be the Bank of Japan's target for this interest rate, and $\mathrm{rrs}_{\mathrm{t}}$ be the ex ante real interest rate, such that 


$$
\begin{aligned}
r r S_{t} & \equiv r S_{t}+\pi_{t-j}^{k} \\
\pi_{t-j}^{k} & \equiv p_{t-j+k}-p_{t-j}
\end{aligned}
$$

$\pi_{t-j}^{k}$ is the inflation rate from period $t-j$ to $t-j+k$. Then express the Bank of Japan's interest rate target function as:

$$
r S_{t}^{0}=E_{t}\left(\pi_{t-j}^{k}\right)+r r S^{*}+\gamma^{p}\left[E_{t}\left(\pi_{t-j}^{k}\right)-\pi^{* k}\right]+\gamma^{i p}\left[E_{t}\left(i p_{t}-i p_{t}^{*}\right)\right]
$$

The * superscripts denote target values, and the expectations operator, $E_{t}$. is conditional on the information set (defined in section 3) available at time t.

Equation (11) indicates that the Bank of Japan targets the nominal interest rate as a function of the expected inflation "gap" and the expected output "gap". When these deviations are zero (so that the target inflation rate and output level are achieved), then the targeted interest rate equals the sum of the expected inflation rate and the target real interest rate.

It is assumed that the Bank of Japan does not exactly set the short term interest rate at its target level; hence the actual interest rate is described by a partial adjustment mechanism, such that it is a weighted average of the target rate, and lagged actual rates, viz.

$$
\begin{gathered}
r S_{t}=\lambda r S_{t}^{0}+(1-\lambda)\left[\sum_{i=1}^{k} w_{i} r S_{t-i}\right]+\epsilon_{t} \\
\quad \text { such that } \sum_{i=1}^{k} w_{i}=1
\end{gathered}
$$

Since the central bank can operationally set the short interest rate exactly, equation (12) is interpreted as a description of internal decision making processes which preclude large and drastic changes in market interest rates.

Returning to equation (11), notice that the specification implies that the target rates are the long run equilibrium rates implied by the VAR used by the central bank. This implies that in setting the targets, the central bank accepts that it cannot affect long run values of the real interest rate and the real level of output (potential GDP). Of course, due to the presence of 
nominal rigidities, the central bank can affect output and real interest rates in the short run.

There is one additional difficulty in modeling the interest rate targeting behavior in Japan which does not arise in the German case. That is that there is a secular decline in both the interest and inflation rates in Japan; both of these variables revert to a mean in Germany. This suggests rewriting equation (5) in terms of a real interest rate target. Shifting the expected inflation term to the left-hand side yields:

$$
\begin{gathered}
x S_{t}^{0}-E_{t}\left(\pi_{t-j}^{12}\right) \equiv \operatorname{rrS} S_{t}^{0} \\
r r S_{t}^{0}=r I S^{*}+\gamma^{D}\left[E_{t}\left(\pi_{t-j}^{k}\right)-\pi^{* k}\right]+\gamma^{i p}\left[E_{t}\left(i p_{t}-i p_{t}^{*}\right)\right]
\end{gathered}
$$

To account for the possibility that the Bank of Japan also targets other variables, such as commodity prices and the real exchange rate, we generate targets for these variables too, and enter them to the regression in a fashion analogous to the manner in which the output gap is entered.

\subsection{Modeling Inflation Gaps}

A key issue is the measurement of expectations of future inflation, and implied gaps, and at what horizon to measure them. Following Clarida and Gertler, we consider three alternatives: one-year-ahead, infinite horizon, and backward looking.

The first one, looking forward one year, is quite reasonable. It sets the expected inflation gap as equal to the expected inflation rate over the next twelve months minus the equilibrium inflation rate over that interval,

$$
E_{t}\left(\pi_{t-j}^{k}\right)=\pi^{* k}=E_{t}\left(\pi_{t}^{12}\right)-\pi^{* 12}
$$

In the second case, the Bank of Japan is concerned with cumulative inflation. In other words, the deviation of interest is the gap between the expected inflation in the infinite future and the equilibrium, also in the infinite future, 


$$
E_{t}\left(\pi_{t-j}^{k}\right)-\pi^{* k}=\lim _{k \rightarrow \infty} E_{t}\left(\pi_{t}^{k}\right)-\pi^{* k}
$$

Since in the long run, the expected must converge to the equilibrium, by substituting in the definitions for $\pi_{\mathrm{t}}{ }^{k}$ and $\pi_{\mathrm{t}}{ }^{* k}$, one obtains the result that:

$$
E_{t}\left(\pi_{t-j}^{k}\right)-\pi^{* k}=-E_{t}\left(p_{t}-p_{t}^{*}\right)
$$

This result means that the central bank will raise interest rates if the equilibrium price level is above the expected current price level (recall that the current price level is not observed at time t). While the reversal of signs is at first glance mysterious, the intuition is straightforward. When the trend price level $\left(\mathrm{p}^{*}\right)$ is above the current level, inflation (the first difference of log prices) is expected to be higher than trend before attaining equilibrium; the central bank therefore wishes to raise interest rates to counter this inflation burst.

The final alternative is the one-year backward looking specification considered by Taylor; it defines the gap as:

$$
E_{t}\left(\pi_{t-j}^{k}\right)=\pi^{* k}=E_{t}\left(\pi_{t-12}\right)-\pi^{* 12}
$$

where the expectation operator is still relevant because the current price level $\left(p_{t}\right)$ used to calculate the inflation rate is not observed at time $t$. We now turn to a discussion of the determination of the long run equilibrium values for inflation and output. It is clear that estimation of such "targets" is of central methodological concern. In the traditional approach, the trend would be defined by the fit from a regression of the actual series on some polynomial in time.

Here we equate target levels with the permanent component of the series (either price levels or output levels). Since the variables of interest appear to be integrated of order one $[I(1)]$, the permanent component from a Beveridge-Nelson (1981) decomposition is a natural variable to use as the 
target. ${ }^{1}$

Consider any nonstationary series, $z$; by the Wold decomposition theorem, the first difference of $z, w_{t}=z_{t}-z_{t-1}$ can be expressed as a moving average process:

$$
w_{t}=\mu+\epsilon_{t}+\lambda_{1} \epsilon_{t-1}+\ldots
$$

The $\epsilon$ 's are called innovations since they are unpredictable on the basis of past information. The expectation of $z_{t+k}$ conditional on time $t$ data is given by:

$$
\begin{aligned}
\hat{z}_{t}(k) & =E\left(z_{t+k} \mid \ldots, z_{t-1}, z_{t}\right) \\
& =z_{t}+\hat{w}_{1}(1)+\ldots+\hat{w}_{t}(k),
\end{aligned}
$$

In words, this means the best forecast of $z$ is equal to the current $z$, plus expected changes between now and period $k$. Using the expression for $w$, one sees the best forecast of $w$ at horizon $i$ is a weighted sum of the past innovations, plus a constant. This fact, combined with the previous equation means that at very long horizons (large $k$ )

$$
\begin{aligned}
& \hat{z}_{t}(k) \approx k \mu+\left[z_{t}+\left(\sum_{1}^{\infty} \lambda i\right) \epsilon_{t}+\left(\sum_{2}^{\infty} \lambda_{i}\right) \epsilon_{t-1}+\ldots\right] \\
& \hat{z}_{t}(k) \approx k \mu+\overline{z_{t}}
\end{aligned}
$$

Beveridge and Nelson identify the terms in the square brackets as the "permanent" component of $z$. This makes sense if one views the "..ppermanent component [as] ...the long run forecast of the series adjusted for its mean rate of change" (Beveridge and Nelson, 1981:156). In practice we set $k=240$ (i.e., 20 years), so that:

$$
\overline{z_{t}}=z_{t}+\operatorname{limit}_{k \rightarrow 240}\left[\hat{w}_{t}(1)+\hat{w}_{t}(2)+\ldots+\hat{w}_{t}(k)-k \mu\right]
$$

Typically, the permanent component is computed using univariate predictions of

This is a common procedure. Clarida and Gertler (1997) as well as Dominguez (1996) define the target rates as the Beveridge-Nelson permanent components of the respective variables. 
w; in this paper the estimates are obtained from the vector error correction model described above.

Figure 7 presents nominal interest, inflation and real interest rates and their respective long run equilibrium values. Figure 8 then presents the infinite horizon inflation and output gaps, while Figure 9 presents the same for commodity prices and the real exchange rate.

\subsection{Empirical Results}

Inflation and output

The results of estimating the reaction function are reported in Table 3 . For the basic specification including only industrial production and inflation gaps, one obtains different results depending upon whether the 12-month ahead inflation gap or the infinite horizon gap is used. If the former is used, the point estimate indicates that the Bank of Japan reduces interest rates in response to a current positive output gap. This is clearly counter-intuitive, although the estimate is not statistically significant.

When the infinite horizon inflation gap is used, the coefficient signs are in accord with theory and statistically significant. A one percent inflation gap induces a 0.43 percentage point increase in interest rates; a one percent output gap induces a .79 percentage point increase. These are remarkably similar to the estimates obtained for the Bundesbank of 0.36 and 0.69 , respectively. The implied equilibrium short rate is $5.42 \% .^{2}$

It is of interest to compare these results to those obtained if one assumes that the real short term interest rate is being targeted, as in equation (5'). Then one obtains the results in Table 4. Once again, the 12month ahead forecast yields an implausible (but not statistically significant) point estimate; it implies the Bank of Japan reduces real interest rates by half a percentage point in response to a one percent inflation gap. In

The backward looking gap failed to produce any meaningful results, as the estimates were of incorrect sign, and not statistically significant. This result makes sense if one believes that the Bank of Japan is looking forward, rather than backward. 
contrast, the infinite horizon forecast produces much more reasonable estimates. They indicate that a one percentage point inflation gap yields a .41 percentage point increase in interest rates; a one percent output gap produces a .85 percent increase. ${ }^{3}$

Overall, the results suggest that indeed the Bank of Japan acts much like other central banks. However, it targets long-horizon inflation gaps as opposed to 12 -month-ahead gaps. ${ }^{4}$

Inflation, Output and Exchange Rates

Given recent work arguing that the Bank of Japan targets the exchange rate as well as inflation and output (see Glick and Hutchison (1994) among others), we investigated whether exchange rate gaps also entered into the Bank of Japan function. We constructed an exchange rate gap similar to the output gap. Using the 12-month ahead forecast for inflation, one obtains the results in the top panel of Table 5 for the nominal short rate. They indicate that the exchange rate target does not enter significantly in either economic or statistical terms.

Since the 12-month-ahead results are not promising, we focus our attention on the infinite horizon results. They imply that an inflation gap of one percentage point induces a .441 increase in interest rates; an output gap induces a .603 increase. Holding all else constant, a one percent exchange rate gap (the Yen $1 \%$ weaker than equilibrium, in real terms) provokes a 0.04 percentage point decrease in the short term rate. Once again, this estimate is not statistically significant.

Considering the secular trends in interest and inflation rates, we restate the equation in terms of real interest rates. The results are reported

While the implied equilibrium real interest rate is fairly high, it is important to remember that the 2 standard errors band would easily encompass a value of zero.

We also implemented regressions allowing for asymmetries in the reaction function, as Clarida and Gertler do. While the point estimates indicate some difference in responses when output is below potential versus when it is above, the difference is not statistically significant. 
in Table 6. In the 12-month inflation horizon case, the output and inflation gap coefficients are not much changed from the nominal interest rate case. However, the exchange rate gap now makes sense -- a one percent gap in the real exchange rate causes the Bank of Japan to raise the real short term interest rate by 10 basis points.

If the infinite horizon is used instead of the 12-month horizon, then one finds that a similar, albeit smaller, response is obtained for the exchange rate gap. The point estimate in the estimated equation is also not statistically significant. This suggests that we have obtained mixed evidence for targeting of the real exchange rate. ${ }^{5}$

\section{Conclusions}

The evidence reported above supports the view that monetary policy in industrial countries is characterized by remarkably simple and similar reaction functions. Central banks adjust a very short term interest rates in response to innovations in prices and output. But it is worth repeating that this is not a simple story that the central bank raises interest rates when inflation is "high" or employment is above trend. To the contrary, the central bank is assumed not to react to the permanent component of shocks to policy goals. This is consistent with the "bygones are bygones" view of monetary policy. This also means that secular changes in the level of inflation, for example, are a martingale with, in the case of Japan, a negative trend.

The commodity gap never enters into the regression with any statistically significant coefficients, so we eschew discussion of those results. 


\section{Appendix
Data Sources and Definitions}

The data is of monthly frequency and covers the period 1974:08-1994:12.

Bank Credit (DC) : "Domestic Credit" (IFS line 32).

Industrial Production (IP): (IFS line 60..c).

Retail Sale (RET) : Retail Sale Value, Index Number in Real Terms, from OECD Main Economic Indicators.

Consumer Price Level (CP): (IFS line 64) for both US and Japan.

Real World Commodity Price (COM) : World Commodity Price Level in US Dollars (IFS line 00176axd) adjusted by US Consumer Price Index (IFS line 00164x).

US Fed Funds Rate (FFR): Short term interest rate (IFS line 60b) .

Japan Short term interest rate (rs) : Call Money Rate (IFS line 60b) [Short term rate between financial institutions].

Money Supply (M): Money (IFS line 34) plus Quasi-money (IFS line 35) deflated by CPI.

Exchange Rate (ER): Yen/Dollar rate (IFS line ae) at end of month. 


\section{References}

Bernanke, Ben and Alan Blinder, 1992, "The Federal Funds Rate and the Transmission of Monetary Policy," American Economic Review 82: 901-921.

Bernanke, Ben and Ilyan Mihov, 1995, "Measuring Monetary Policy," mimeo (Princeton University).

Beveridge, S: and C. Nelson, 1981, "A New Approach to the Decomposition of Time Series into Permanent and Transitory Components, " Journal of Monetary Economics 7: 141-174.

Blanchard, Olivier, 1989, "A Traditional Interpretation of Economic Fluctuations," American Economic Review 79: 1146-1164.

Chinn, Menzie and Michael Dooley, 1996, "Asia-Pacific Capital Markets: Measurement of Integration and the Implications for Economic Activity, " NBER Working Paper \#5280 (September). Forthcoming in T. Ito and A.O. Krueger, (eds.) Regionalism versus Multilateral Trading Arrangement (Chicago U. Press for NBER: Chicago) : 169-196.

Clarida, Richard and Mark Gertler, 1997, "How the Bundesbank Conducts Monetary Policy," in Reducing Inflation: Motivation and Strategy," in C. Romer and D. Romer (eds.) (Chicago U. Pres for NBER: Chicago), pp. 363-412. Also NBER Working Paper \#5581 (May 1996).

Dominguez, Kathryn M.E., 1996, "Monetary Interdependence and Coordination," Mimeo (Kennedy School of Government, Harvard University, July).

Gali, Jordi, 1992, "How Well Does the IS/LM Model Fit Post-War U.S. Data?" Quarterly Journal of Economics 107:709-738.

Glick, Reuven and Michael Hutchison, 1994, "Monetary Policy, Intervention, and Exchange Rates in Japan," in Glick and Hutchison (eds.) Exchange Rate Policy and Interdependence: Perspectives from the Pacific Basin (Cambridge, UK: Cambridge University Press), pp. 225-257.

Hamada, Koichi and Fumio Hayashi, 1985, "Monetary Policy in Postwar Japan, " in Ando, Eguchi, Farmer and Suzuki (eds.) Monetary Policy in Our Times

(Cambridge, MA: MIT Press), pp. 83-121.

Hutchison, Michael, 1988, "Monetary Control with an Exchange Rate Objective: The Bank of Japan, 1973-86," Journal of International Money and Finance, $7: 261-71$.

Ito, Takatoshi, 1989, "Is the Bank of Japan a Closet Monetarist? Monetary Targeting in Japan, 1978-88," NBER Working Paper No. 2874.

Kasa, Kenneth and Helen Popper, 1995, "Monetary Policy in Japan: A Structural VAR Analysis" Federal Reserve Bank of San Francisco, Pacific Basin Working Paper, No. PB95-12.

McCallum, Bennett, 1993, "Specification and Analysis of a Monetary Policy Rule for Japan," Bank of Japan Monetary and Economic Studies, 11.

Pierce, James, 1984, "Did Financial Innovation Hurt the Great Monetarist Experiment?" American Economic Review 74: 392-95.

Stuart, Alison, 1996, "A Simple Monetary Policy Rule," Bank of England ouarterly Bulletin 31(3) (August): 281-287. 
Taylor, John, 1993, "Discretion versus Policy Rules in Practice," CarnegieRochester Conference on Public Policy, pp. 195-214.

Walsh, Carl, 1993, "What Caused the 1990-1991 Recession?" Federal Reserve Bank of San Francisco Economic Review, 1993 (2), pp. 33-48. 
Table 1

Structural VAR Estimates From Over-Identified Model

$$
\begin{aligned}
& u^{m}=0.00265 u^{r e t}-0.3925 u^{r s}+e^{m} \\
& \text { (0.041) (2.2984) } \\
& u^{r s}=\underset{0.0008)}{0.00033} u^{c o m}+\underset{(0.0036)}{0.0008} u^{m}+\underset{(0.0031)}{0.0024} u^{e r}+e^{r s} \\
& u^{\text {er }}=-0.0332 u^{\text {com }}-0.0333 u^{\text {ip }}+0.1900 u^{\text {ret }}-0.1717 u^{c p}+0.3292 u^{d c} \\
& \begin{array}{lllll}
(0.1040) & (0.2044) & (0.1701) & (0.6505) & (0.4415)
\end{array} \\
& -44.9251 u^{\mathrm{rs}}+12.1830 \mathrm{u}^{\mathrm{ffr}}-0.0846 \mathrm{u}^{\mathrm{m}}+\mathrm{e}^{\mathrm{er}} \\
& \begin{array}{lll}
(9.3268) \quad(4.1076) \quad(0.3547)
\end{array}
\end{aligned}
$$

Notes: The sample is 1974:08 - 1994:12. Estimation is done by instrumental variables. For the $\mathrm{u}^{\mathrm{rs}}$ equation the instruments are $\mathrm{u}^{\mathrm{com}}, \mathrm{u}^{\mathrm{p}}, \mathrm{u}^{\mathrm{ret}}, \mathrm{u}^{\mathrm{cp}}, \mathrm{u}^{\mathrm{dc}}$. For the $\mathrm{u}^{\mathrm{m}}$ equation, the instruments are $\mathrm{u}^{\mathrm{con}}, \mathrm{u}^{\mathrm{ip}}, \mathrm{u}^{\mathrm{ret}}, \mathrm{u}^{\mathrm{cp}}, \mathrm{u}^{\mathrm{dc}}, \mathrm{e}^{\mathrm{rs}}$. For the $\mathrm{u}^{\mathrm{er}}$ equation, the instruments are $u^{\mathrm{com}}, u^{i p}, u^{\text {ret }}, u^{c p}, u^{d c}, e^{r s}, e^{m}$. Standard errors in parentheses. 
Table 2

Variance Decomposition for the Nominal Interest Rate

Sample 1974:08. 1994:12

$\begin{array}{ccccccccccc}\text { Horizon } & \mathrm{e}^{\text {com }} & \mathrm{e}^{\mathrm{ip}} & \mathrm{e}^{\mathrm{cpl}} & \mathrm{e}^{\mathrm{ret}} & \mathrm{e}^{\mathrm{dc}} & \mathrm{e}^{\mathrm{ffr}} & \mathrm{e}^{\mathrm{m}} & \mathrm{e}^{\mathrm{rs}} & \mathrm{e}^{\mathrm{er}} & \\ 6 & 2.98 & 3.28 & 0.71 & 0.89 & 0.66 & 7.48 & 0.10 & 81.76 & 2.10 \\ 12 & 7.15 & 2.67 & 0.96 & 0.63 & 0.94 & 23.28 & 0.47 & 57.64 & 6.23 \\ 24 & 13.83 & 2.38 & 2.66 & 0.73 & 1.64 & 42.16 & 1.59 & 29.52 & 5.44 \\ 48 & 11.26 & 5.01 & 5.58 & 1.75 & 1.52 & 50.08 & 4.77 & 16.81 & 3.19\end{array}$




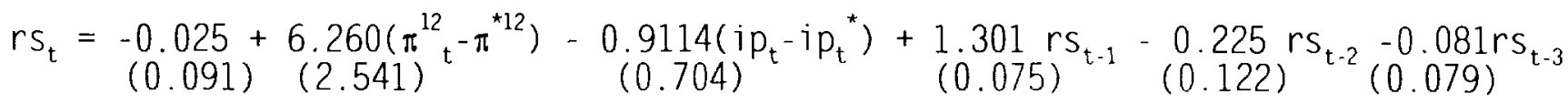

The sample is 1975:9-1994:12. Estimation is done by instrumental variables. The

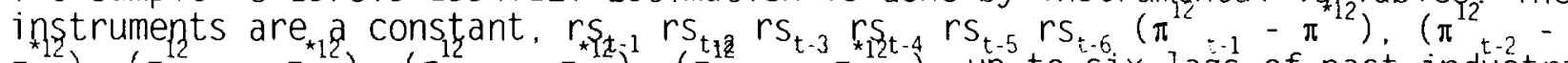

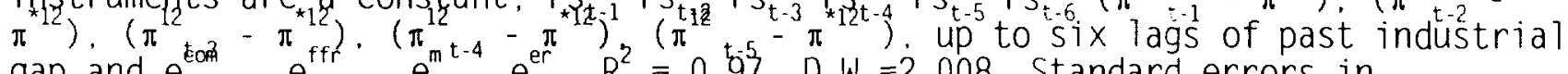

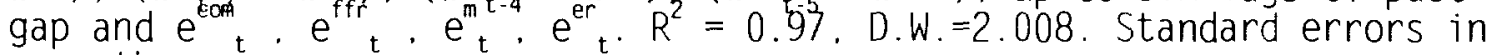
parentheses.

Implied Equation for the Target Day to Day Rate

$n / a$

Infinite Horizon Inflation Forecast

Dynamic Partial Adjustment Equation

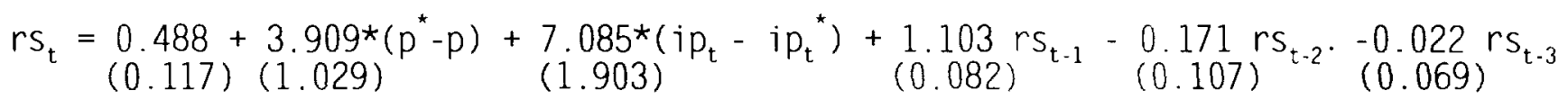

The sample is 1975:9-1994:12. Estimation is done by instrumental variables. The

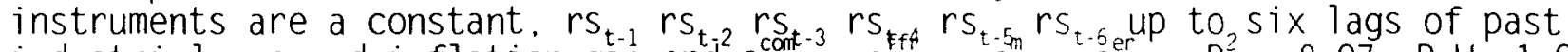

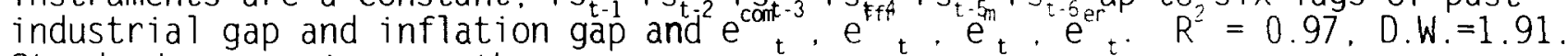
Standard errors in parentheses.

\section{Implied Equation for the Target Day to Day Rate}

$r s_{t}^{0}=5.422+43.430 *\left(p_{t}^{*}-p_{t}\right)+78.720 *\left(i p_{t}-i p_{t}^{*}\right)$ 
Table 4

Bank of Japan Reaction Function, Ex Ante Real Rate

12 Month Inflation Forecast

Dynamic Partial Adjustment Equation

$$
\begin{aligned}
& r s_{t}= 2.065-16.650\left(\pi^{12}{ }_{t}-\pi^{* 12}\right)+42.452\left(i p_{t}-i p_{t}^{*}\right)+0.052 r s_{t-1}- \\
&(0.707)(12.287)(0.094) \\
& 0.606 r s_{t-2}-0.003 r s_{t-3} \\
&(0.147) \\
&(0.088)
\end{aligned}
$$

The sample is 1975:9-1994:12. Estimation is done by instrumental variables. The

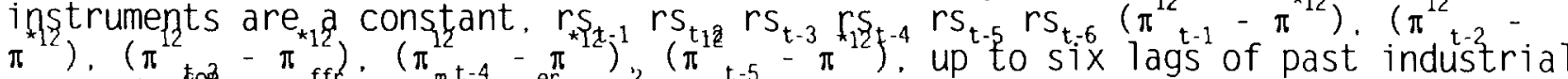
gap and $e^{\text {tad }}{ }_{t}, e^{\mathrm{ffr}}, \mathrm{t}_{\mathrm{t}}, \mathrm{e}_{\mathrm{t}}^{\mathrm{t}-4}, \mathrm{e}_{\mathrm{t}}^{\mathrm{er}} \cdot \mathrm{R}^{2}=0.59, \mathrm{D} \cdot \mathrm{W} .=1.794$. Standard errors in parentheses.

Implied Equation for the Target Day to Day Rate

$$
\mathrm{rs}_{\mathrm{t}}{ }^{0}=6.090-49.118^{*}\left(\pi^{12}{ }_{\mathrm{t}}-\pi^{{ }^{12}}\right)+125.23^{*}\left(i p_{\mathrm{t}}-i p_{\mathrm{t}}{ }^{*}\right)
$$

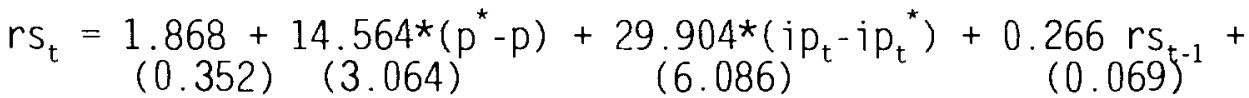

$$
\begin{aligned}
& 0.115 \mathrm{rs}_{\mathrm{t}-2}+0.267 \mathrm{rs}_{\mathrm{t}-3} \\
& (0.074) \quad(0.062)
\end{aligned}
$$

The sample is 1975:9-1994:12. Estimation is done by instrumental variables. The instruments are a constant, $r s_{t-1} r s_{t-2} r_{c o r t-3} r s_{t f f} r s_{t-s_{m}} r s_{t-6 e r}$ up to six lags of past industrial gap and inflation gap and $e_{t}^{\text {comt }-3}, e_{t}, e_{t}, e_{t} \cdot R^{2}=0.67,0 . W .=1.90$. Standard errors in parentheses.

$$
\text { Implied Equation for the Target Day to Day Rate }
$$

$r s_{t}^{0}=5.307+41.376^{*}\left(p_{t}^{*}-p_{t}\right)+84.958 *\left(i p_{t}-i p_{t}^{*}\right)$ 
Bank of Japan Reaction Function, Nominal Interest Rate Exchange Rate Gap Included

\section{Month Inflation Forecast}

Dynamic Partial Adjustment Equation $r s_{t}=0.254+3.535 *\left(\pi^{12}{ }_{t}-\pi^{* 12}\right)+5.722 *\left(i p_{t}-i p_{t}^{*}\right)-0.029\left(e r_{t}-e r_{t}{ }^{*}\right)+$
$(0.220)(3.730)$
$(5.191)$ $(0.512)$

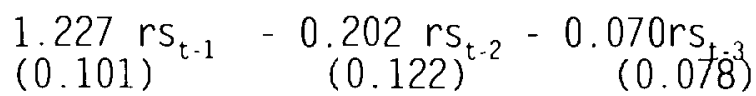

The sample is 1975:9-1994:12. Estimation is done by instrumental varjables, The

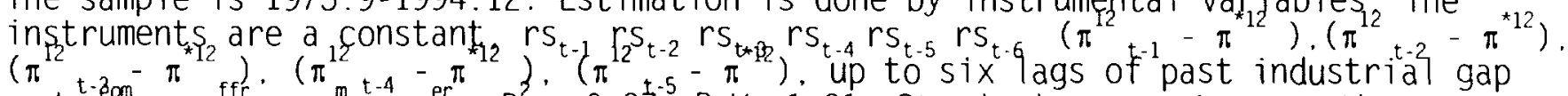

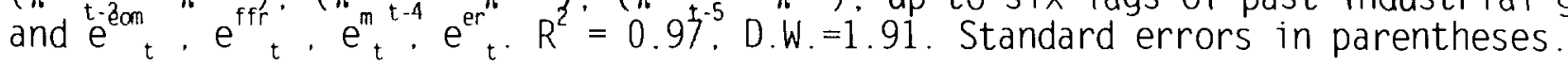

Implied Equation for the Target Day to Day Rate

$$
r s_{t 0}=5.644+78.556^{*}\left(\pi^{12}{ }_{t}-\pi^{* 12}\right)+127.14 *\left(i p_{t}-i p_{t}^{*}\right)-0.644 *\left(e r_{t}-e r_{t}{ }^{*}\right)
$$

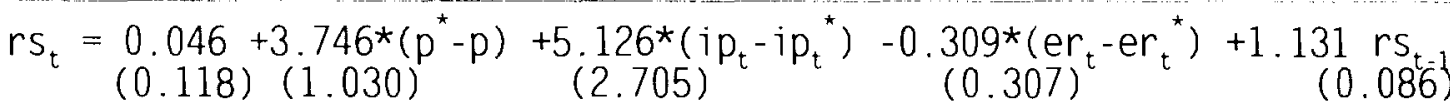

$$
\begin{aligned}
& (0.071)
\end{aligned}
$$

The sample is 1975:9-1994:12. Estimation is done by instrumental variables. The instruments are a constant, $r s_{t-1} r s_{t-2} r s_{c o n t-3} r s_{t f f} r s_{t-s_{m}} r s_{t-6 e r}$ up to six lags of past industrial gap and inflation gap and $\mathrm{e}_{\mathrm{t}}^{\text {cont }-3} \cdot \mathrm{e}_{\mathrm{t}}, \mathrm{e}_{\mathrm{t}}, \mathrm{e}_{\mathrm{t}} \cdot \mathrm{R}^{2}=0.97, \mathrm{D} \cdot \mathrm{W}=1.95$. Standard errors in parentheses.

Implied Equation for the Target Day to Day Rate

$$
r s_{t}^{0}=5.432+44.072 *\left(p_{t}{ }^{*}-p_{t}\right)+60.311 *\left(i p_{t}-i p_{t}^{*}\right)-3.637 *\left(e r_{t}-e r_{t}{ }^{*}\right)
$$


Table 6

Bank of Japan Reaction Function, Real Interest Rate

Exchange Rate Gap Included

12 Month Inflation Forecast

Dynamic Partial Adjustment Equation

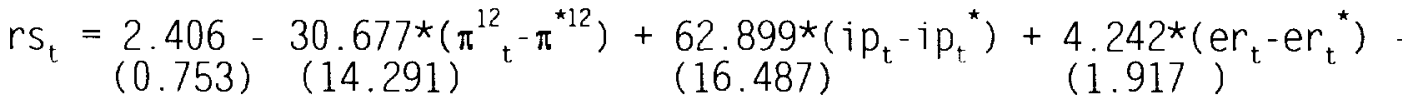

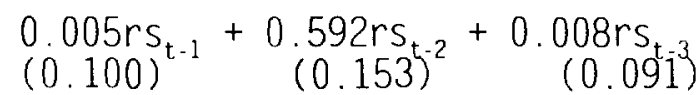

The sample is 1975:9-1994:12. Estimation is done by instrumental variables. The instruments are a constant. $r s_{12-1} r s_{t-2 \times 12} r s_{t-3} r s_{t-4} r s_{t-5} r s_{t-6}\left(\pi_{t-1}^{12}-\pi^{* 12}\right) .\left(\pi^{12} \cdot-\pi^{* 12}\right)$,

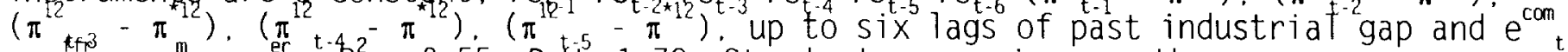
, $\mathrm{e}_{\mathrm{t}}^{\mathrm{kte}}, \mathrm{e}_{\mathrm{t}}^{\mathrm{m}}, \mathrm{e}_{\mathrm{t}}^{\mathrm{er}} \cdot \mathrm{R}^{2}=0.55,0 . \mathrm{W}^{5}=1.78$. Standard errors in parentheses:

Implied Equation for the Target Day to Day Rate

$r s_{t}^{0}=5.941-75.742 *\left(\pi^{12}-\pi^{* 12}\right)+155.297 *\left(i p_{t}-i p_{t}^{*}\right)+10.473 *\left(e r_{t}-e r_{t}^{*}\right)$

Infinite Horizon Inflation Forecast

Dynamic Partial Adjustment Equation

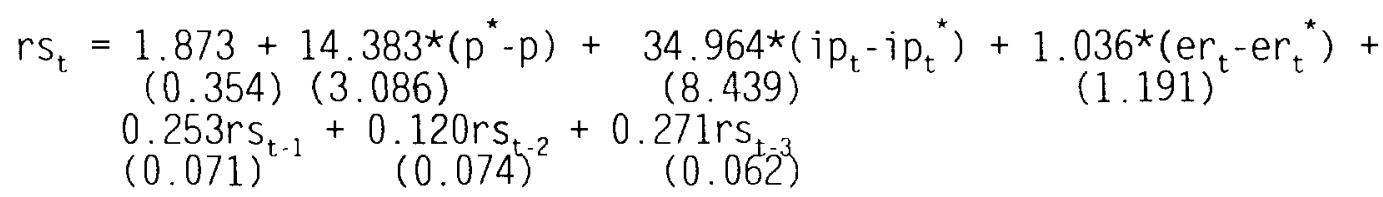

The sample is 1975:9-1994:12. Estimation is done by instrumental variables. The instruments are a constant. $r s_{t-1} r s_{t-2} r s_{c o n t-3} r s_{f-4} r s_{n t-5} r s_{t-6}$ up to six lags of past

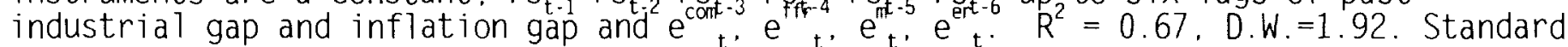
errors in parentheses.

Implied Equation for the Target Day to Day Rate

$r s_{t}^{0}=5.261+40.402^{\star}\left(p_{t}^{*}-p_{t}\right)+98.214 *\left(i p_{t}-i p_{t}^{*}\right)+2.910 *\left(e r_{t}-e r_{t}^{*}\right)$ 
Figure 1 Short Term Interest Rate
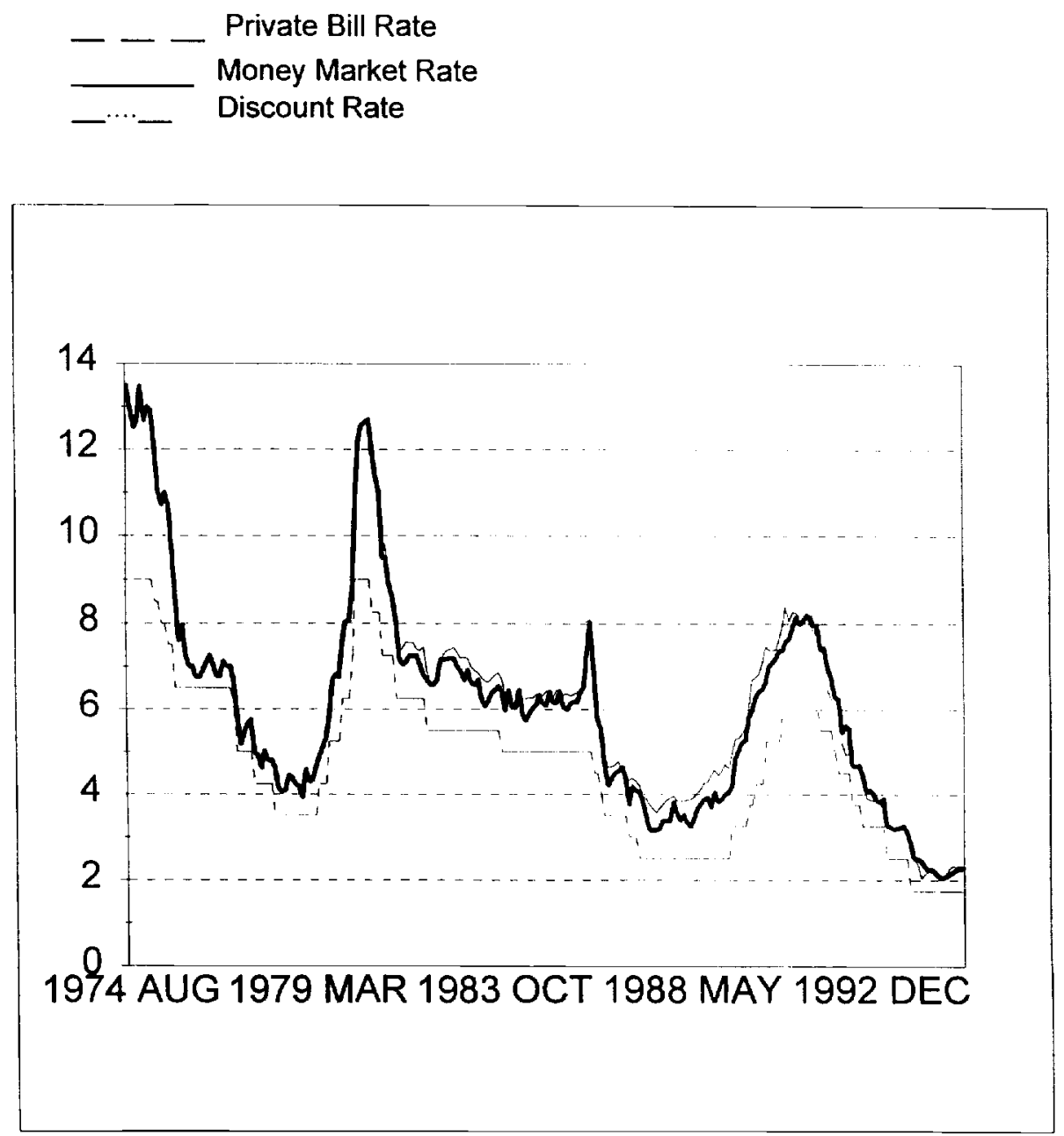
Figure 2 Inflation, Output Growth and Interest Rates

Sample 1974:09..1994:12

\section{Inflation}

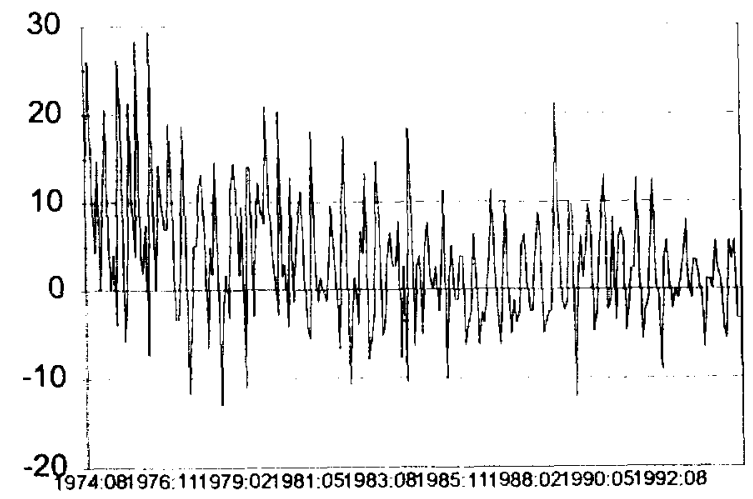

\section{Output Growth}

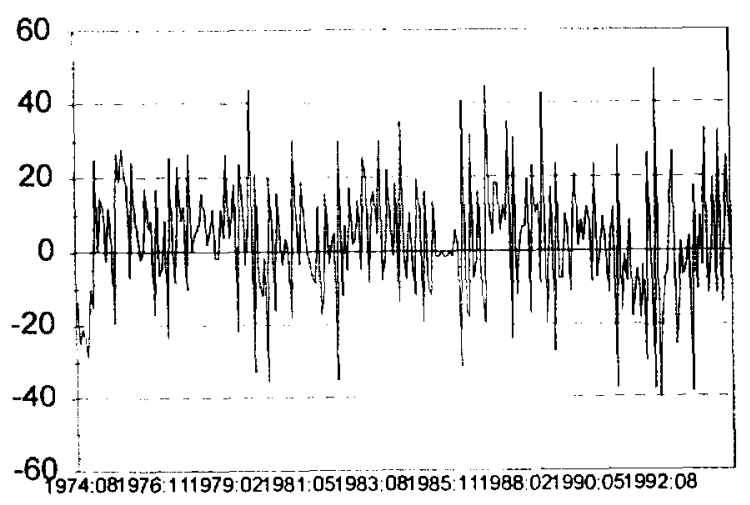

\section{Interest Rates}

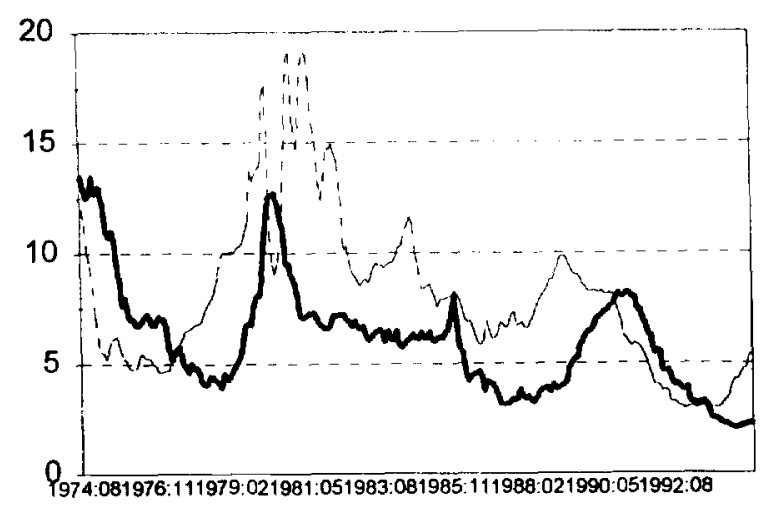


Figure 3 Exchange Rates and Interest Rates

Sample 1974:08 1994:12

\section{Real Exchange Rate (Yen/Dollar)}

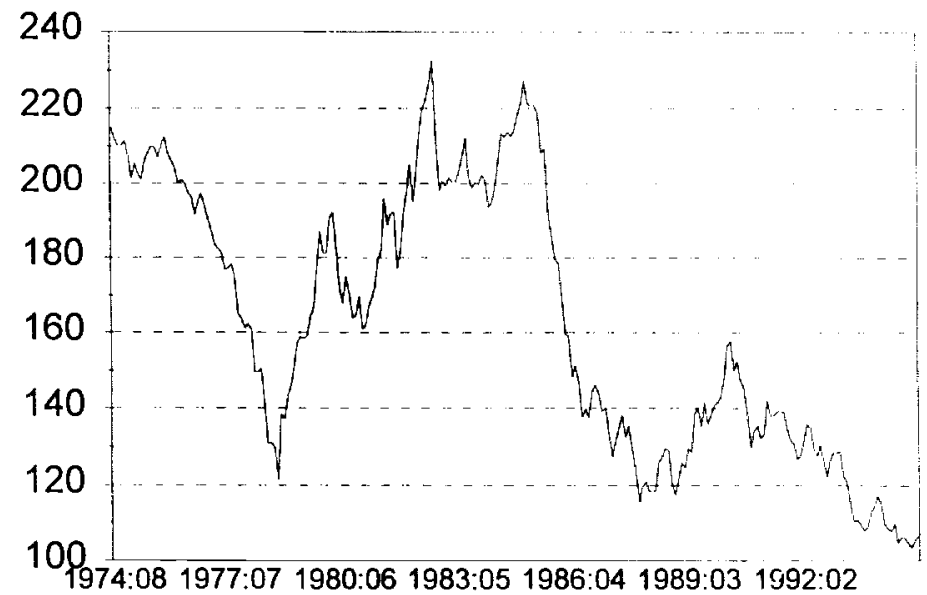

\section{Interest Rates}

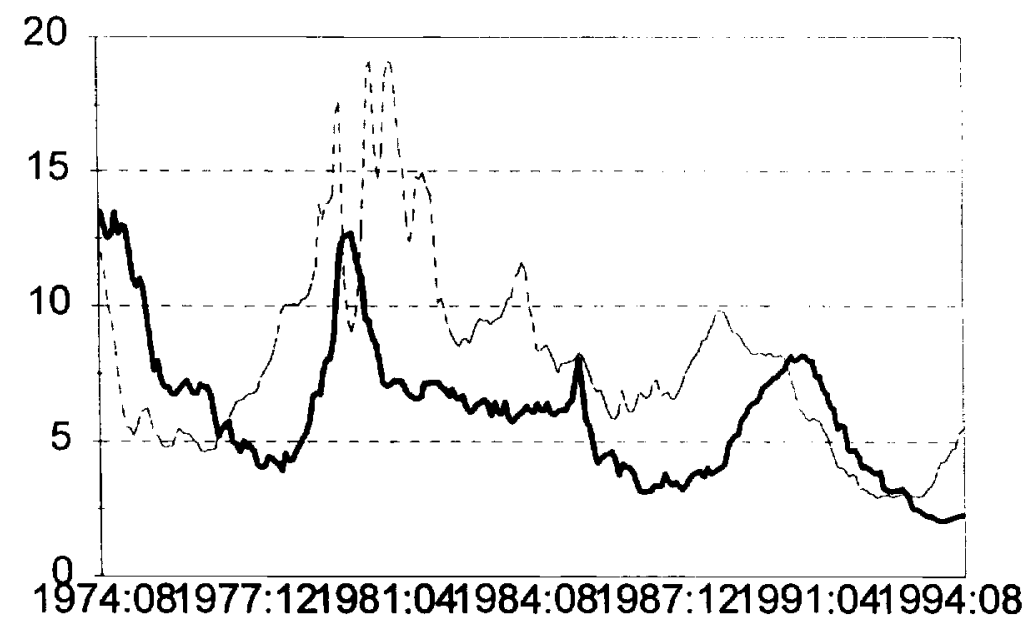

Japan Money Market Rate $\quad \ldots \quad$ Fed Fund Rate 
Figure 5.A Impulse Response to IP Shock

Response of Industrial Production

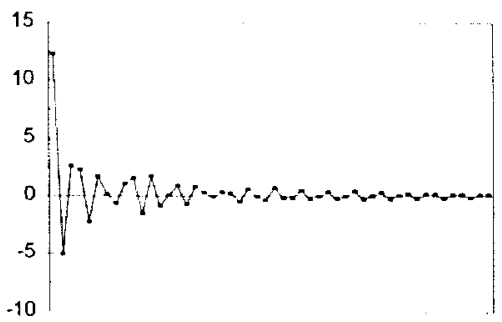

Response of Inflation

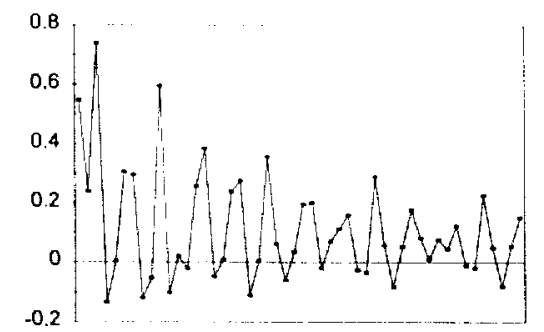

Response of Interest Rate

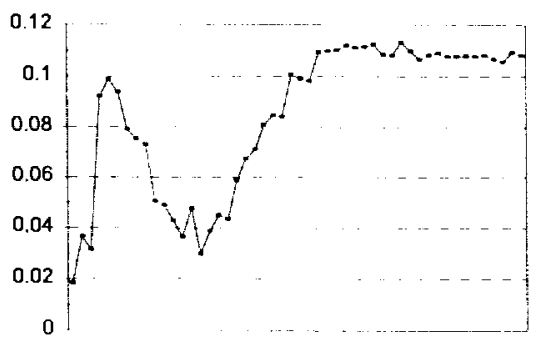

Response of Real Exchange Rate

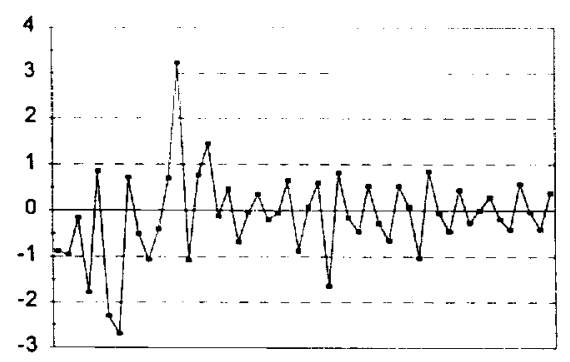

Shcok to Industrial Production

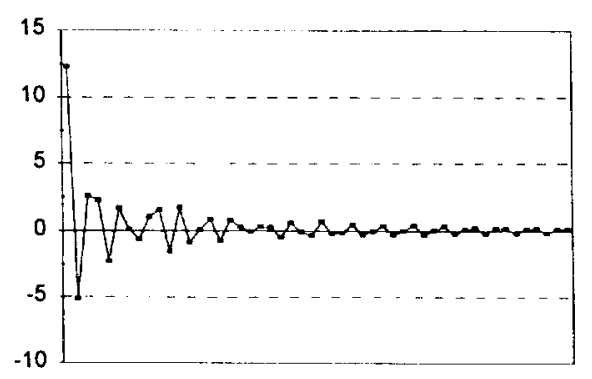


Figure 5.A Impulse Response to Inflation Shock Response of Industrial Production

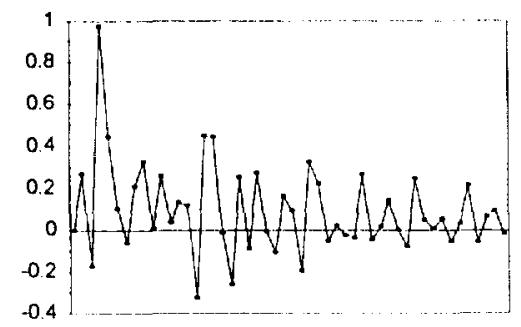

Response of Inflation

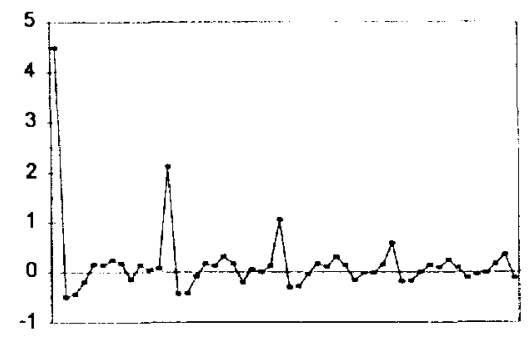

\section{Response of Interest Rate}

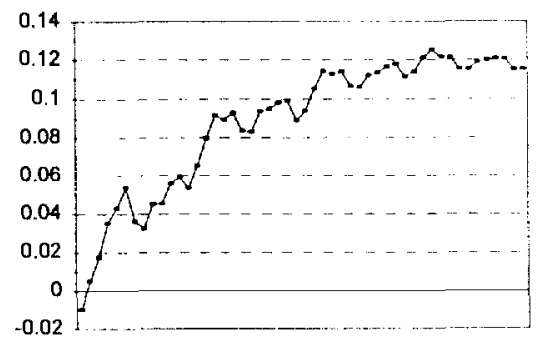

Response of Real Exchange Rate

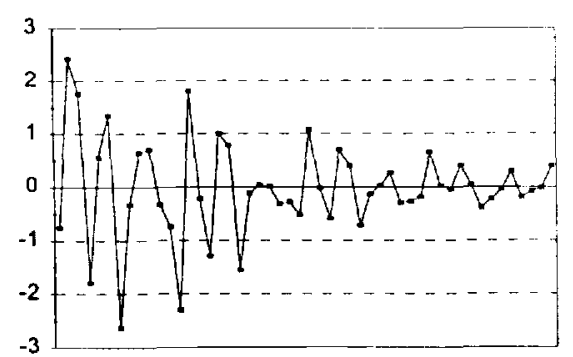

Shock to Inflation Rate

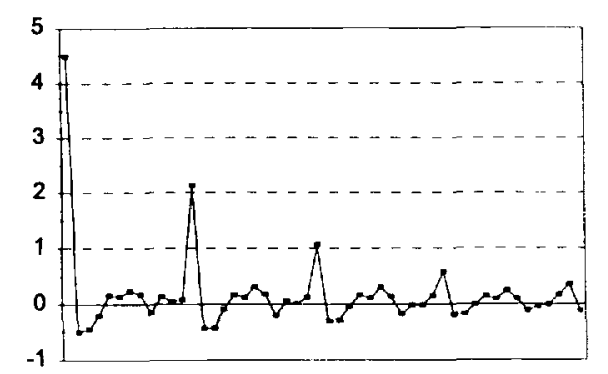




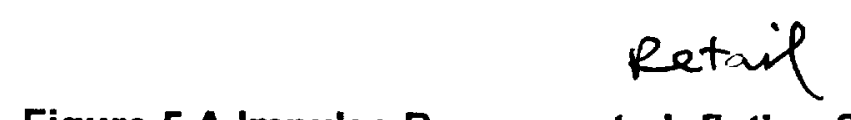

Figure 5.A Impulse Response to tation Shock

Response of Industrial Production

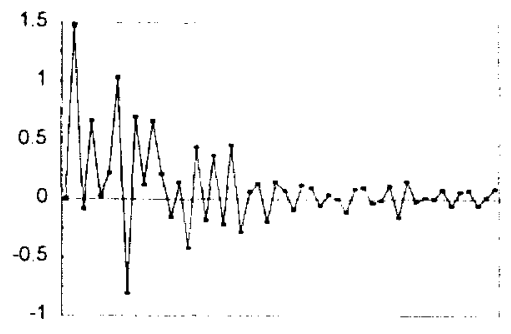

Response of Inflation

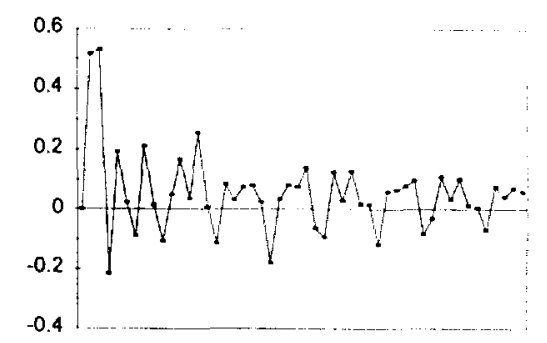

Response of Interest Rate

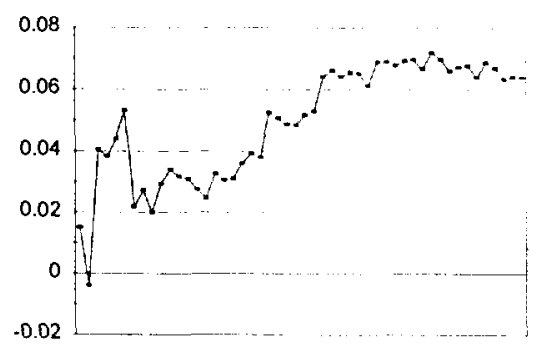

Response of Real Exchange Rate

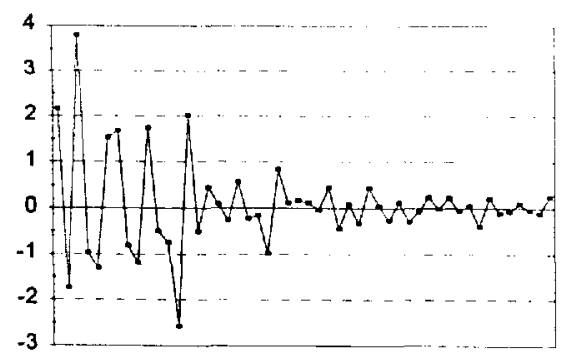

Shock to Retail Sale

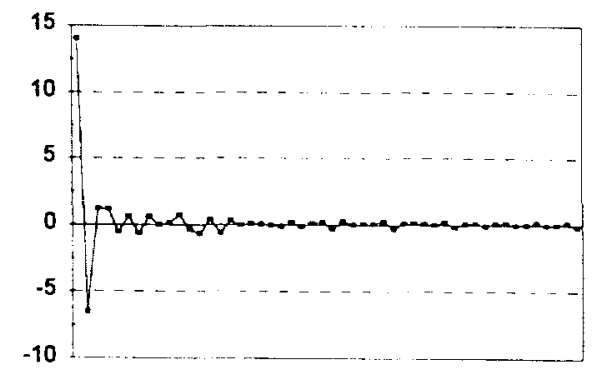


Figure 5.A Impulse Response to Domestic Credit Shock Response of Industrial Production

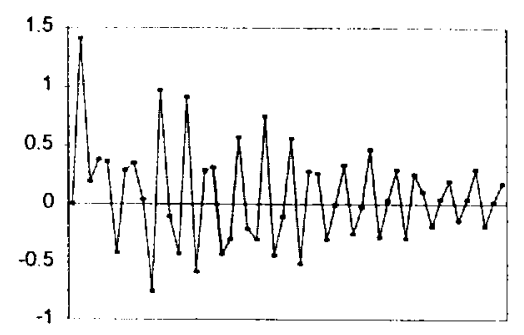

Response of Inflation

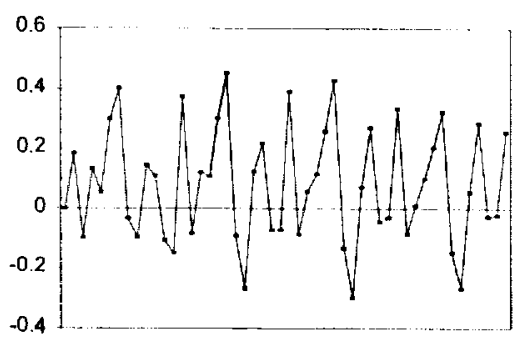

Response of Interest Rate

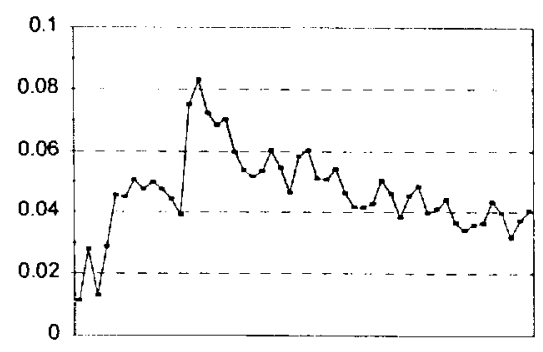

Response of Real Exchange Rate

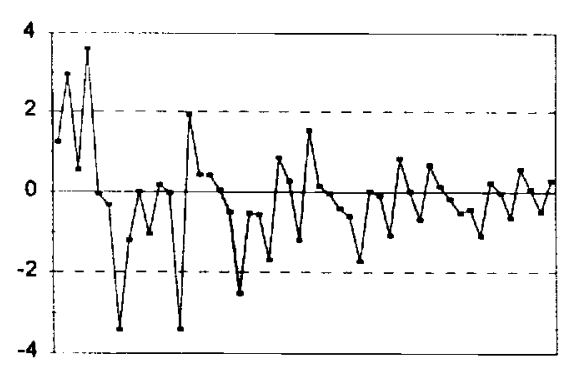

Shock to Bank Credit

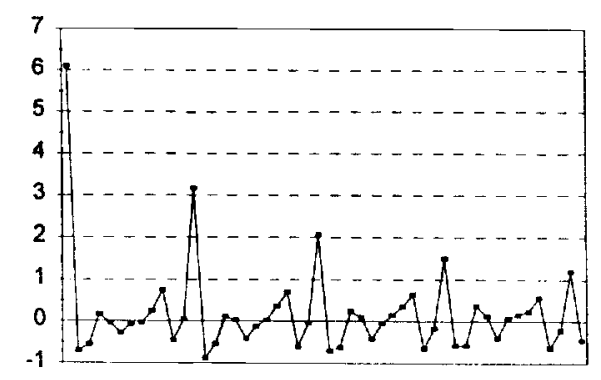


Figure 5.A Impulse Response to Fed Fund Shock

Response of Industrial Production
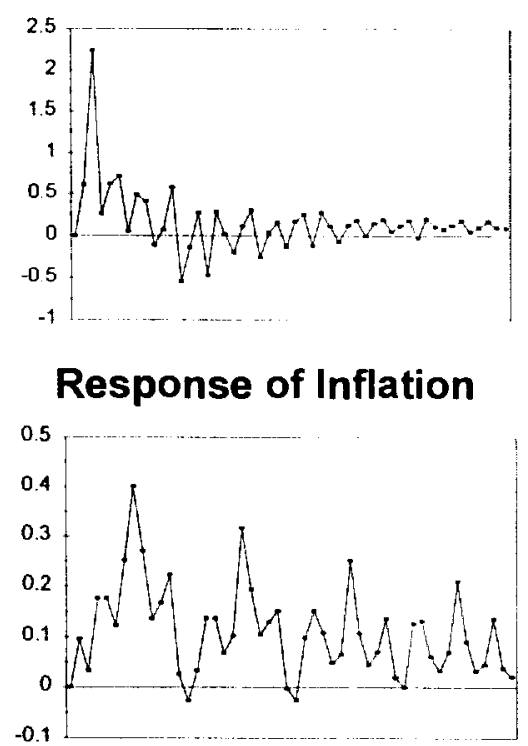

Response of Interest Rate

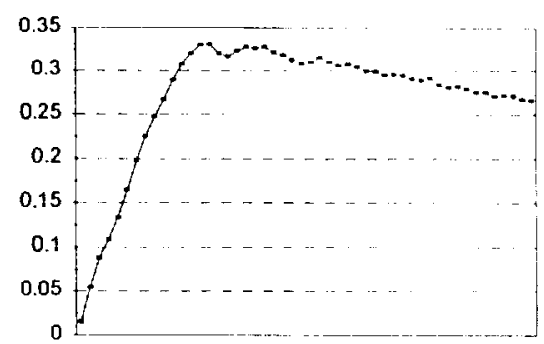

Response of Real Exchange Rate

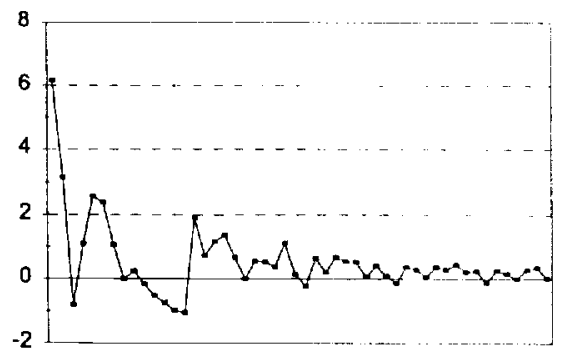

\section{Shock to Fed Fund Rate}

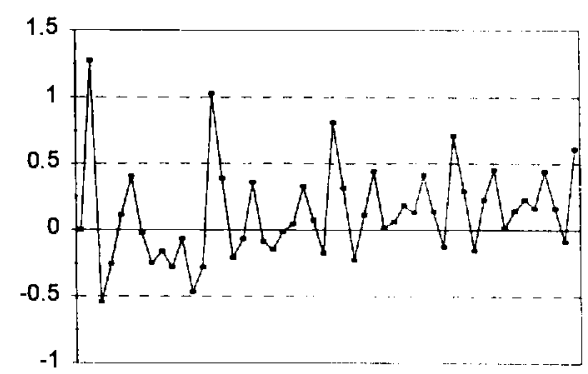


Figure 5.A Impulse Response to Money Shock Response of Industrial Production
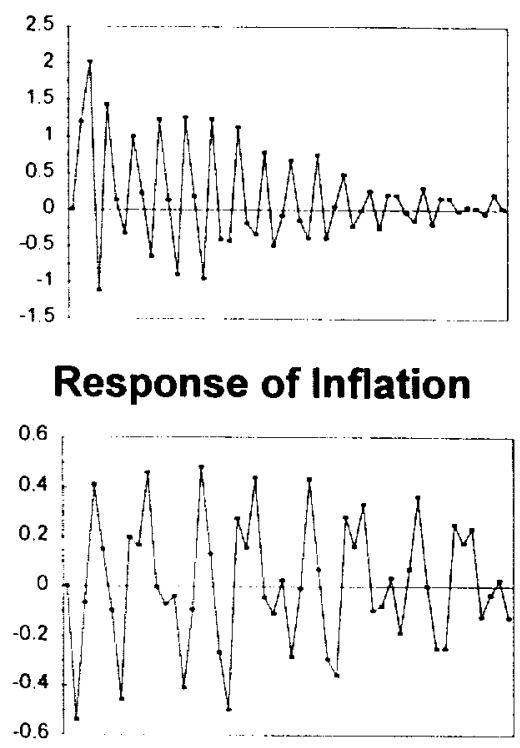

\section{Response of Interest Rate}

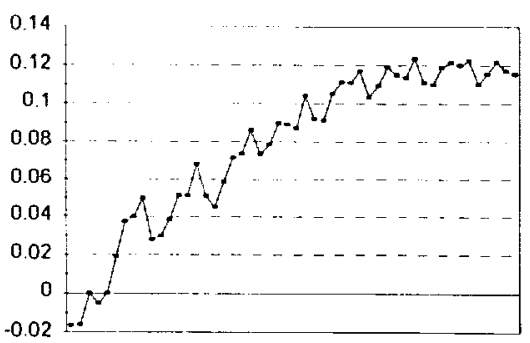

Response of Real Exchange Rate

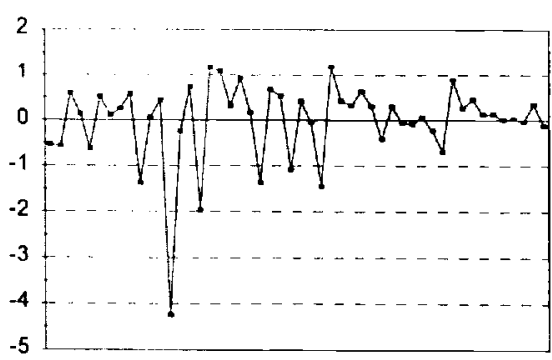

Shock to Money Demand

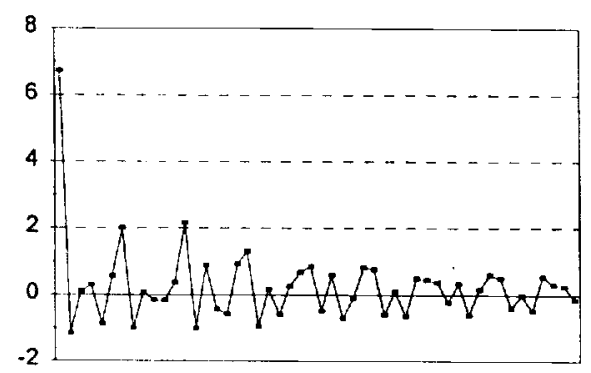


Figure 5.A Impulse Response to Nominal Rate Shock

Response of Industrial Production

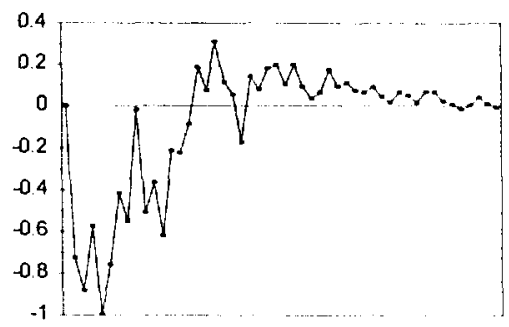

\section{Response of Inflation}

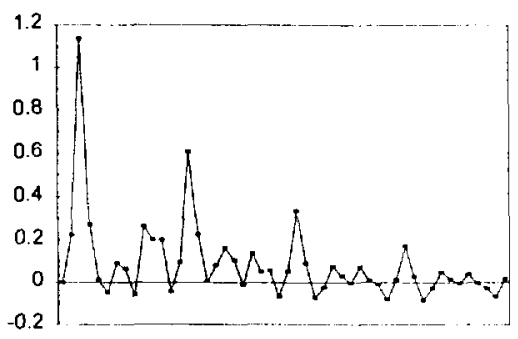

Response of Interest Rate

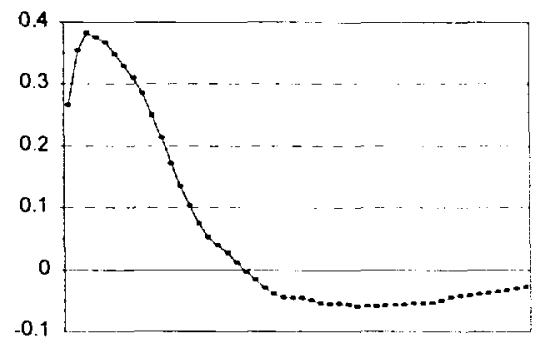

Response of Real Exchange Rate

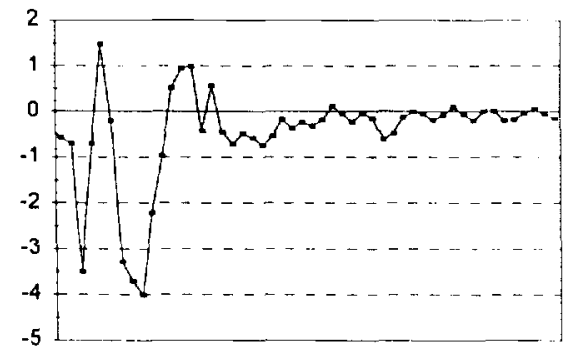

Shock to Nominal Rate

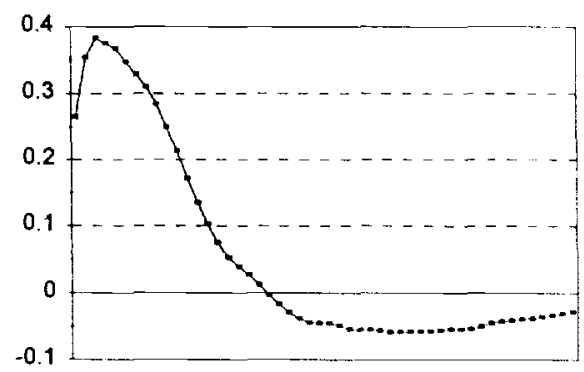


Figure 5.A Impulse Response to Real Exchange Rate Sho Response of Industrial Production

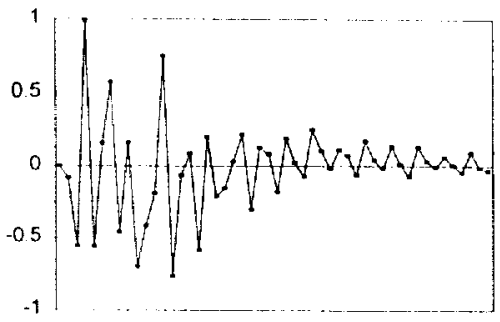

Response of Inflation

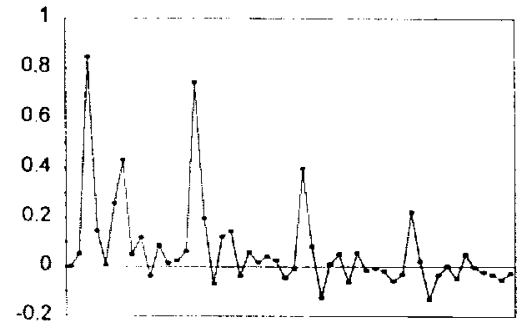

Response of Interest Rate

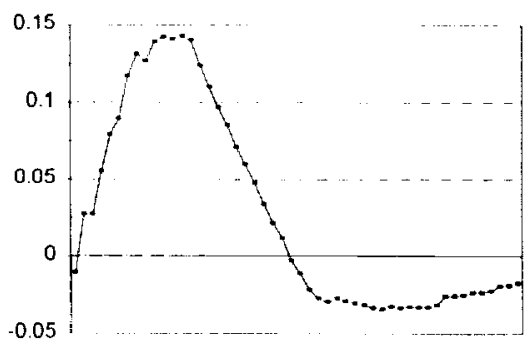

Response of Real Exchange Rate

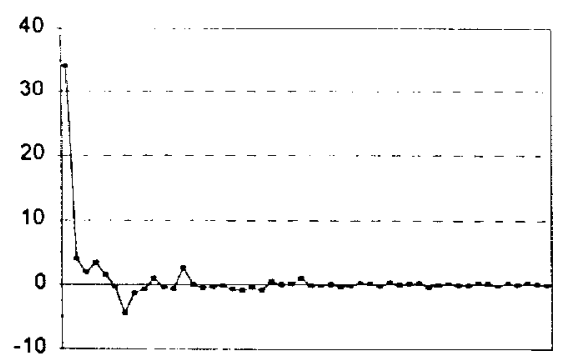

Shock to Real Exchange Rate

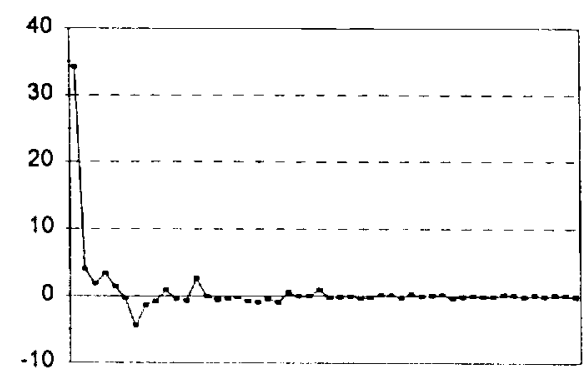


Figure 5.A Impulse Response to Commodity Price Shock Response of Industrial Production
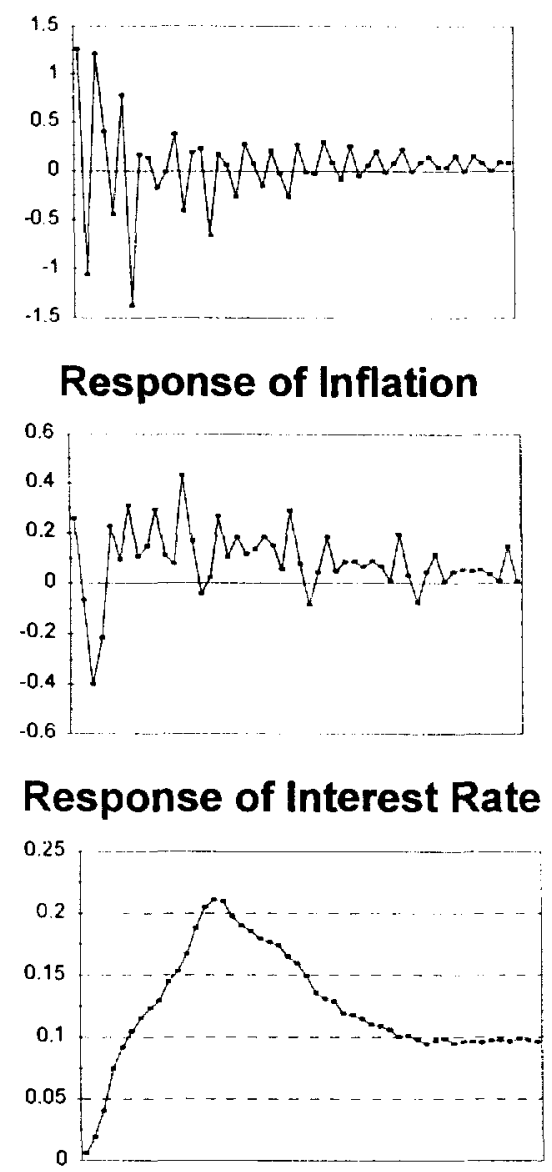

Response of Real Exchange Rate

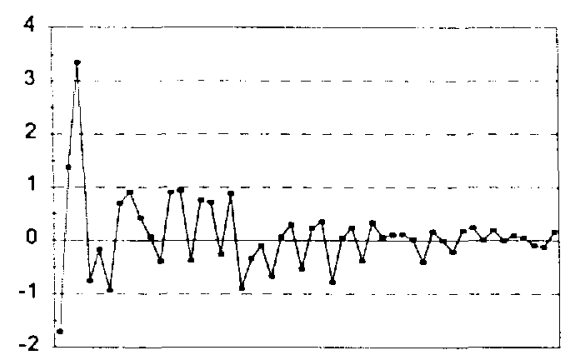

Shock to Commodity Price

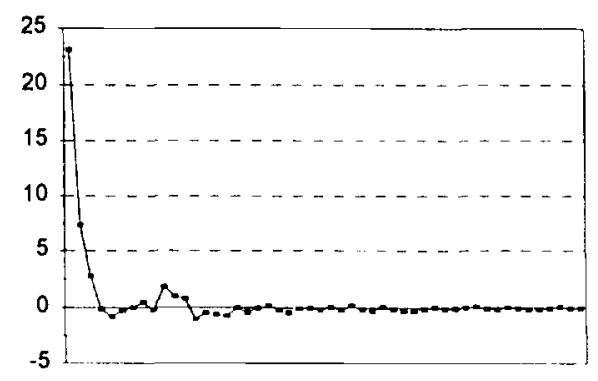




\section{Figure 6 Historical Decomposition of Interest Rate}

\section{News of Short Term Rate}

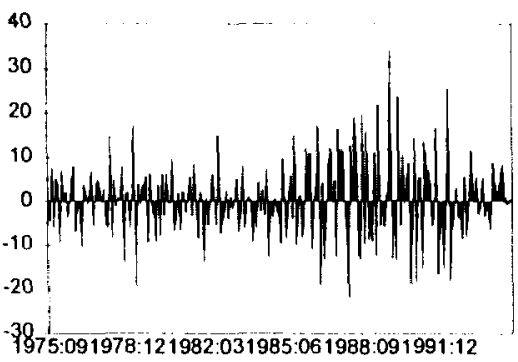

Due to Commodity Price Shock

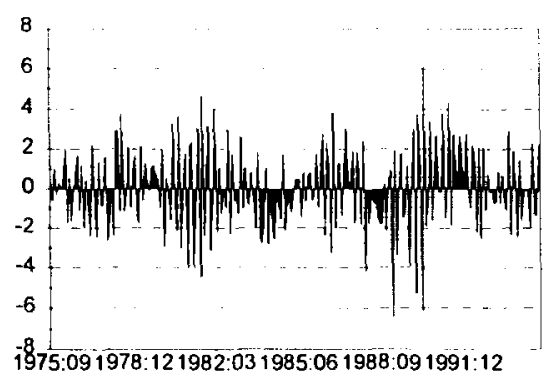

Due to Industrial Production Shock
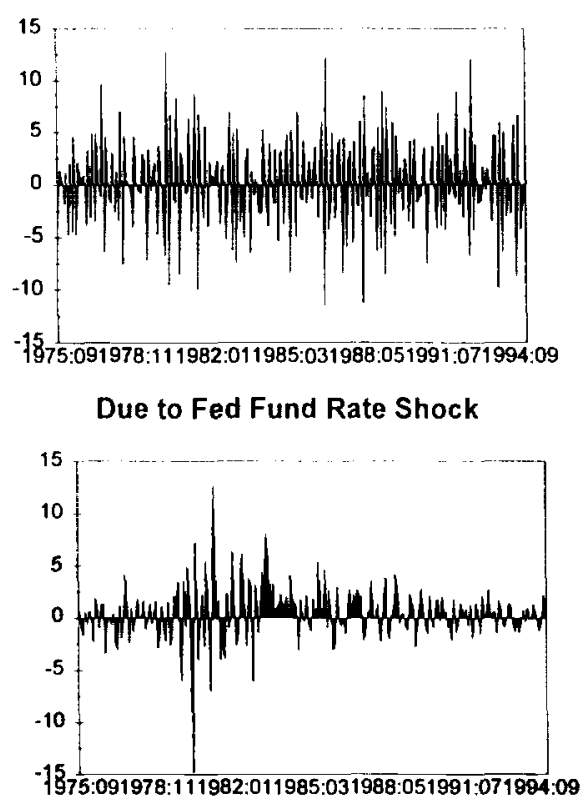

Due to Real Exchange Rate Shock

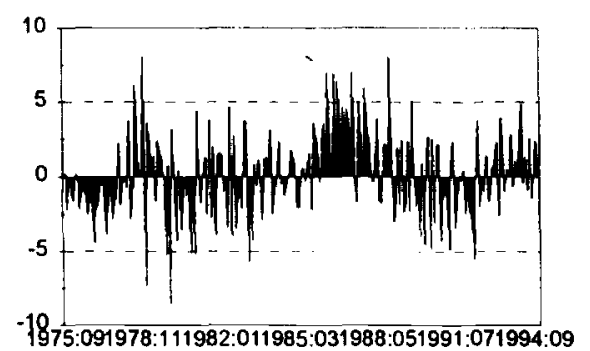


Figure 7 Interest Rates and Inflation

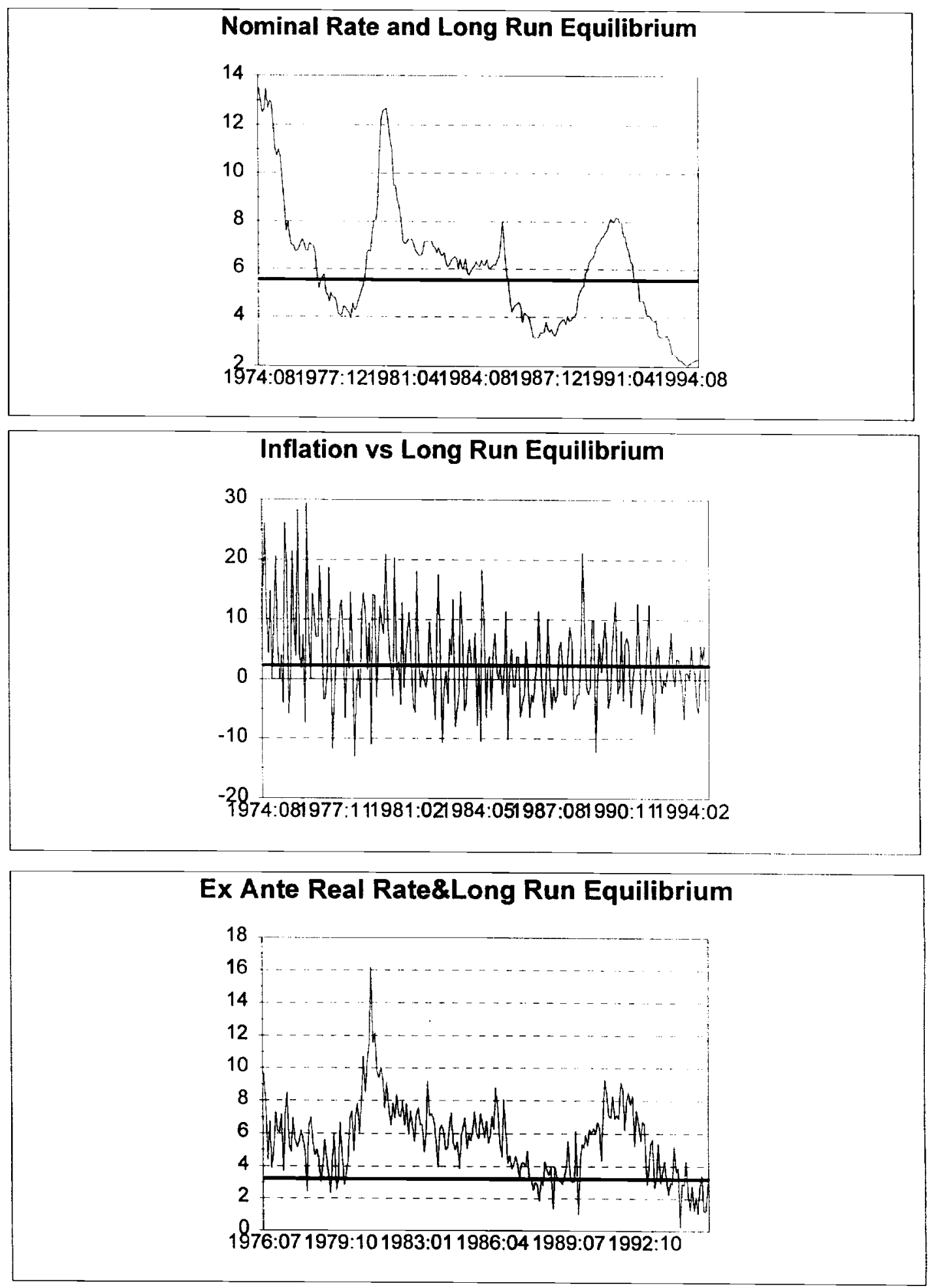


Figure 8 Inflation Gap,Output Gap and Interest Rate

Infinite Horizon case, here is 20 years ahead

\section{Inflation Gap}

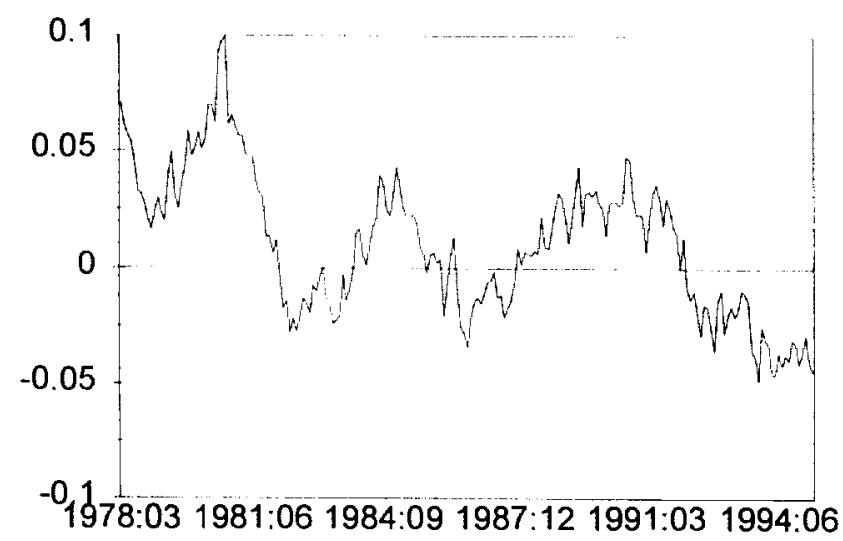

Output Gap

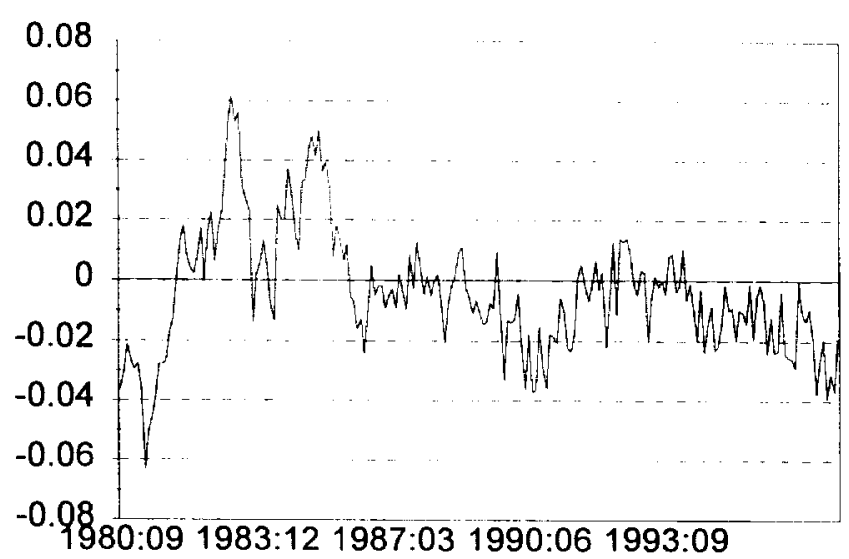

Interest Rate

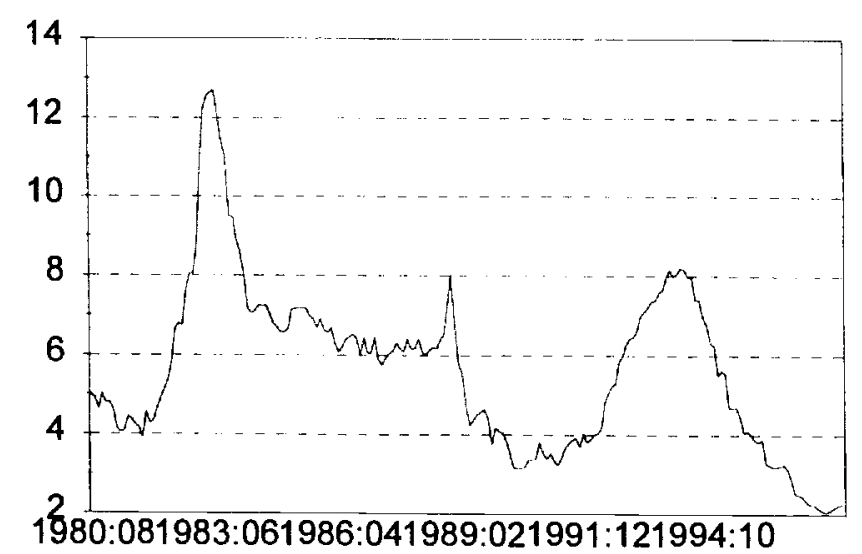


Figure 8.A Commodity Price Gap, Real Exchange Rate Gap and Interest Rate Infinite Horizon case, here is 20 years ahead

\section{Commodity Price Gap}
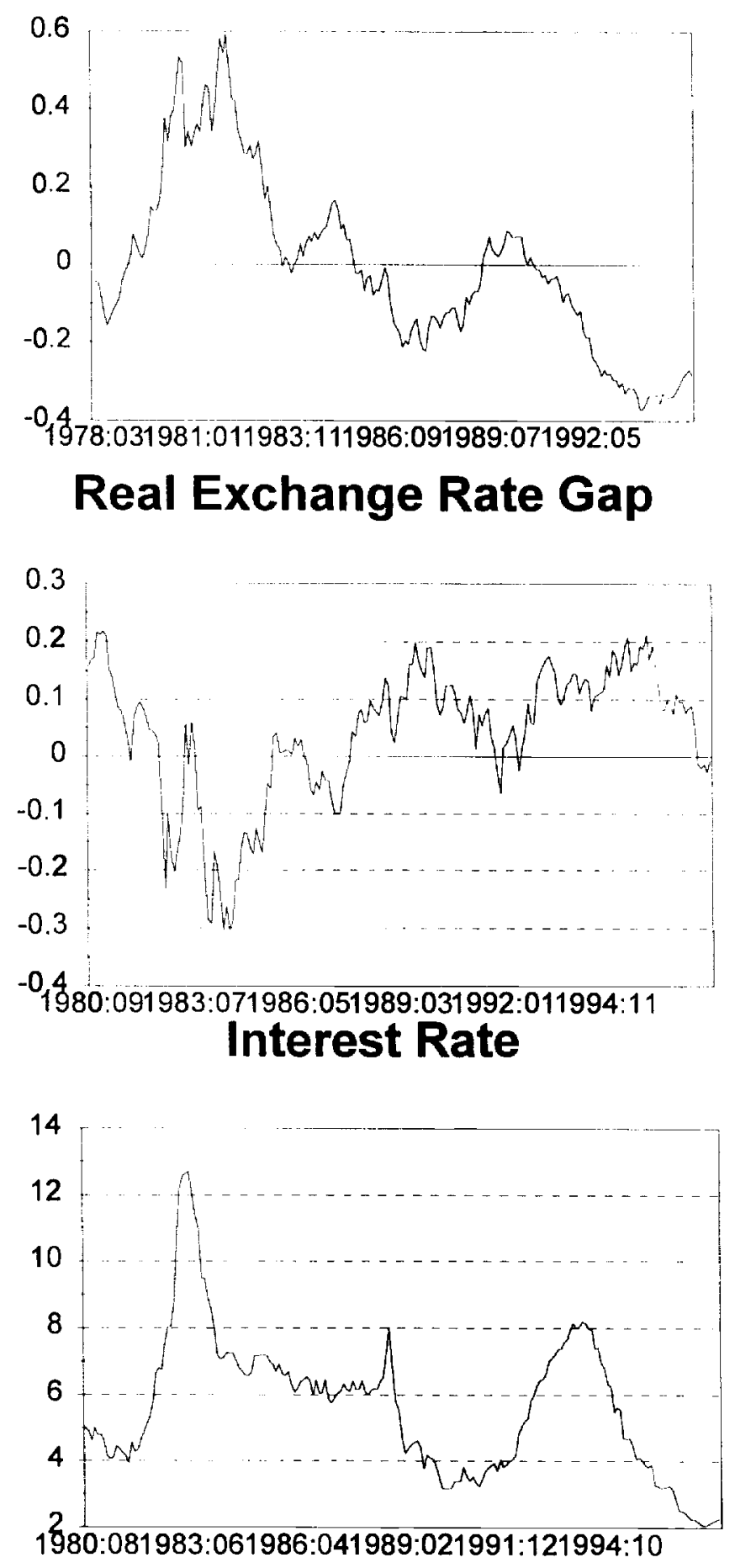